\title{
RACK-RAILWAY LOCOMOTIVES OF THE SWISS MOUNTAIN RAILWAYS.
}

By Mr. J. Weber, Mavaging Director, AND Mr. S. ABT, Works ENGINeER, of the Swiss Locomotive and Engine Works, Winterthur.

\section{[Translated from the German.]}

General.-The first rack-railway locomotive was tested by John Blenkinsop on the 12th August 1811, that is to say almost one hundred years ago, on the Middleton Mineral Line, near Leeds. On the outside of one rail corrugated teeth were cast, into which the driving wheel geared, which was outside the carrying wheel. Rimber in 1831 in America proposed placing a rack in the centre between the two rails, and this idea was carried out by Cathcart in 1847 on the Madison-Indianapolis Railway.

Blenkinsop did not know that the friction between the rail and the wheel was sufficient to provide for the progress of the locomotive and the traction of the train. It was not until 1813

NoTE.-For other particulars of these railways, see Paper on Electric Traction in Switzerland, by Mr. E. Huber-Stockar (page 449). 
that Blackett, owner of the pits at Wylam, showed that this was possible, and subsequently Stephenson built his locomotive as a purely adhesive engine.

Owing to the rapid and enormous development of the railways, many improvements were made in'. comotive construction, and great progress was attained. The necessity of dealing with heavy trains and lines with very steep gradients naturally called for heavy locomotives with an increased number of coupled wheels, which required special designs in the carrying parts of the locomotive in order that they might be in a position safely to deal with curves, at the same time offering the lowest resistance. This led to the adoption of axles with lateral play, the double engines designed by Fairlie, Meyer, Mallet, etc.

The mountainous nature of the country in Switzerland gave particular opportunity for designing mountain locomotives. In normal adhesion railways a gradient was permissible up to $2 \frac{1}{2}$ per cent. (the Gotthard Railway), and in secondary railways one had gone up to as much as 5 per cent. (South Eastern Ruilway). The Uetli Mountain Railway formed an exception as it had gradients of 6.7 per cent., and the purely adhesion locomotive which is used on this line can, when developing its utmost power, draw a train after it of a weight equal to itself.

Experience has shown that for mountain railways the limit for adhesion loconotives was a maximum of 4 per cent., but it was better not to go higher than $3 \frac{1}{2}$ per cent., and that if the railway had steeper gradients than this, rack-gear should be used.

For railways on the mixed system of driving by adhesion and by rack-gear, 12 per cent. gradient should not be exceeded in view of an economical working of the system.

On purely rack railways gearing vertically into the rack (Riggenbach, Abt and Strub systems), it is to be recommended that the maximum gradient should not exceed 25 per cent. By careful and very heavy design of the road when the rack is maintained in very good condition, combined with suitable design of the locomotives, particularly their brakes, a safe working of the line can be ensured both when the trains are ascending or 
descending. For gradients up to 30 per cent. it is necessary to be most accurate in the control of the rack-teeth, as when the train is braked going down banks, very small differences assist the rackwheel to mount on the rack.

If the contour of the country necessitates a still steeper gradient, it is necessary to use a rack with lateral gearing (Locher's system).

Mr. N. Riggenbach, locomotive superintendent of the Central Swiss Railway in Olten, who brought the first ordinary locomotive into Switzerland in 1847, was the builder of the first rack-railway locomotive for the Vitznau-Rigi Railway. In 1862 Riggenbach brought out a special form of rack-and-rack locomotive. In 1868 he travelled in North America, where he saw the Mount Washington line, which was the first rack-railway built on proper principles with locomotives which worked well and had been supplied by Messrs. Baldwin, in Philadelphia. In 1869 he returned from America, and he built a mixed system of railway, having taken the Mount Washington Railway as his pattern. This line was of the ordinary gauge and ran to the quarries in Ostermundingen, near Berne. The same year he, in conjunction with Messrs. Naeff and Zschokke, obtained the concession for a railway to Vitznau on the Rigi. This line was opened in the year 1871, and with this opening the rack-railways were introduced in Switzerland.

Construction of Rack.-The whole systems of racks which are used in Switzerland have been designed in the country itself.

Riggenbach's rack used on the Vitznau-Rigi Railway, Fig. 54 (page 542), was an improvement and a variation on Marsh's rack, as the cheeks formerly made by angle irons were replaced by $[$ irons, and instead of the cylindrical form of the tooth the taper form was adopted. This form of evolute teeth was maintained by all the following rack systems, as it produces a simple form of tooth and permits the gear locking at different depths. The form of Riggenbach rack is exceedingly efficient in preventing the cog-wheels from mounting, and it gives great security against the engine going off the road.

In order to produce safe interlocking of the cog-wheelk, the 
position of which is dependent upon the play of the springs, large diameters of wheels are to be chosen with small pitch, 80 to $100 \mathrm{~mm} .(3 \cdot 15$ to $3 \cdot 94$ inches $)$.

The rack formed also like a ladder, and designed by Mr. Klose (for the St. Gallen-Gais Railway) resembles the Riggenbach rack.

The ends of the teeth are lodged in round holes in the cheek, and their turning is prevented by a rib rolled on to the carrier. For the new line between Lauterbrunnen and Wengen, the L. v. Roll Berne works have made the same construction of rack.

Roman Alt published his arrangement of rack in 1882, Fig. 55.

FIG. 54.-Riggenbach System.
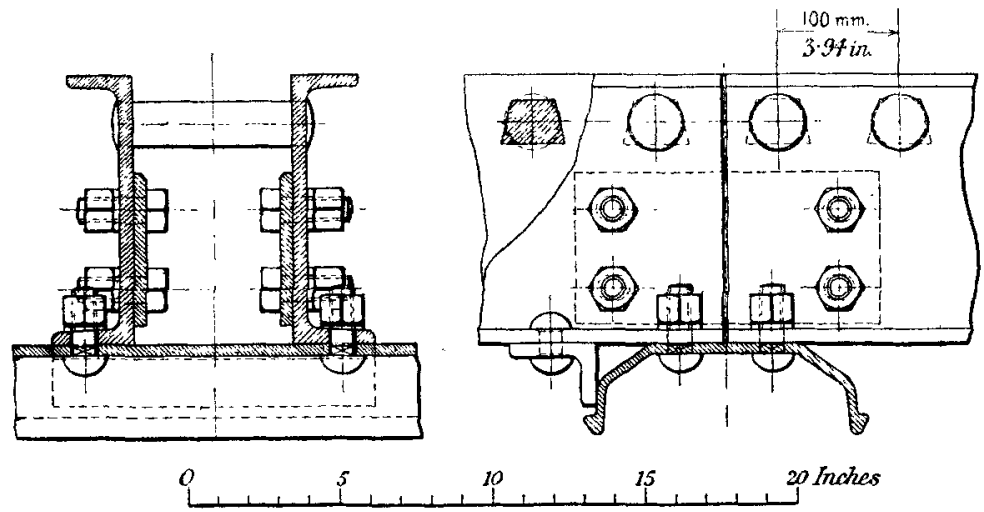

In Switzerland it was first used on the Mount Generoso Railway in 1890. The rack consists of flat-toothed plates, of which two or three, according to the tractive power, are bolted together on chairs in such a way that the tooth of one plate in regard to the other is displaced of half or one-third of the pitch. This pitch amounts to $120 \mathrm{~mm} .(4 \cdot 7$ inches $)$. The Abt system of rack ensures a quiet motion of gearing, and permits the trains to work at high speed. It is specially applicable to long railways on the mixed system. The Abt rack has been adopted the most, and now about $520 \mathrm{~km}$. (323 miles) are fitted with it. It is constructed by the Union Dortmünd and by Cammell, Laird and Co., of Sheffield.

The rack designed by Colonel Edward Locher, Fig. 56 (page 544), 
was used in the year 1888 on the Pilatus Railway, which has a maximum gradient of 48 per cent. The arrangement consists of a plate having gear teeth on each side of it, into which two gearwheels drive, placed opposite to each other; these rack-plates, being riveted to a Vautrin rail, which is so rolled that guide-dises can be provided on the gear wheel, ensure a correct guiding of the vehicle and prevent riding of the wheels. The pitch is $85 \cdot 7 \mathrm{~mm}$. $(3.37$ inches). The heavy gradient necessitates a road very solidly built in masonry, the whole being properly anchored down.

Strub's rack, shown on Fig. 57 (page 545), is a broad-footed

FIG. 55.

Abt System.
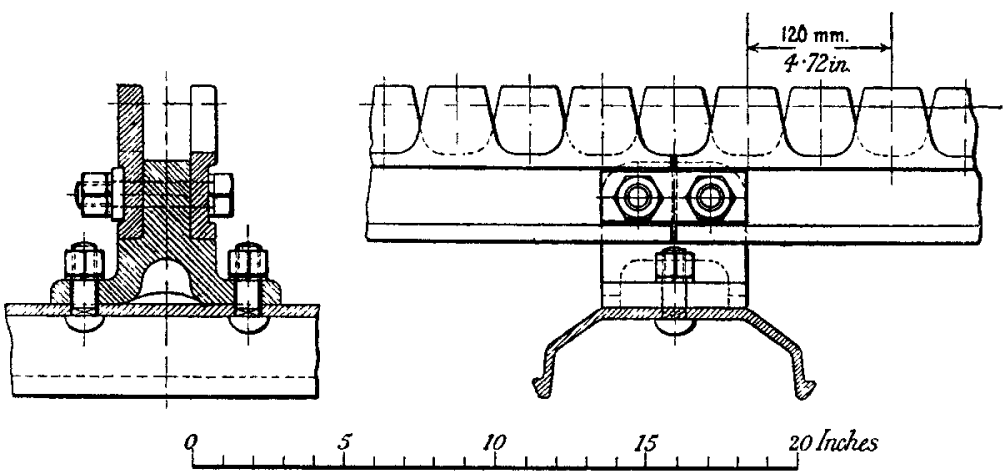

toothed rail having a wedge-formed top, similar to the rail which is used on rope railways, provided with clamp brake-gear. This head of the rack furnishes a good guide for the safety-grips; the latter, however, have not proved to be satisfactory when worked as brakes.

Strub's rack gear was first put into use in 1898 at the Jungfrau Railway. The pitch is generally $100 \mathrm{~mm}$. (3.94 inches). The Berne foundry of $\mathrm{L}$. v. Roll has taken over its construction.

\section{Steam Locomotives.}

(The Map, Fig. 58, page 546, shows the railways on which the following locomotives are at present working.) 
(a) Loconotives with Rack-Gear only.-As already stated on page 541, in May 1871, the now well-known Vitznau-Rigi Railway was opened as the first European rack-railway for passenger traffic. The gauge is the ordinary English gauge. The line has a length of $7,058 \mathrm{~m} .(4 \cdot 38$ miles) and gradients from 6 per cent. up to 25 per cent., the mean gradient being 20 per cent. The curves have $180 \mathrm{~m}$. (591 feet) radius. The original road was built with longitudinal and cross sleepers, but between 1885 and 1895 the road was rebuilt,

\section{FiIG. 56.-Locher System.}

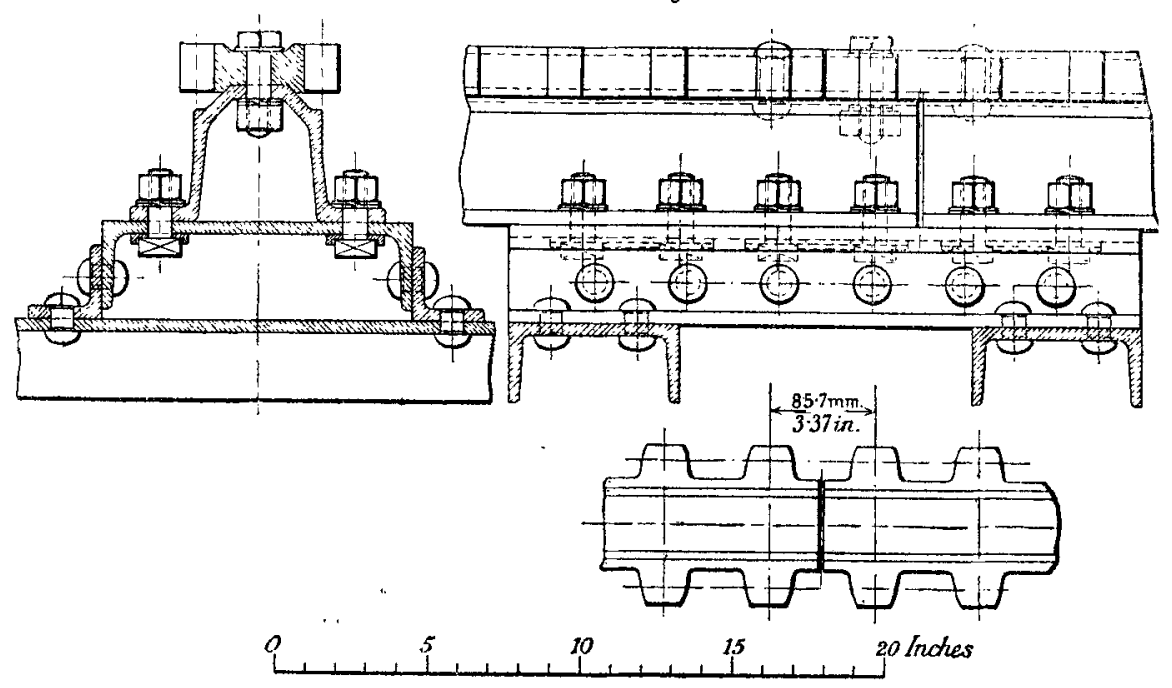

the timber sleepers being replaced by iron ones, and the iron rails being replaced byisteel rails.

The first locomotive for this line was built in the works of the Central Railway in Olten; the engine had a vertical boiler similar to the engines on Mount Washington in order to reduce as much as possible the variations in water-level arising from the different gradients over which the engines worked. The following locomotives were built at the Swiss Locomotive Works in Winterthur, and are the first work turned out by that firm. After eleven years' use the vertical boilers were replaced by horizontal ones. 
Fig. 59 (page 547) shows the vertical boiler engine carried on two axles, on the lower of which is mounted running loose the driving cog-wheel which is driven by gearing from the crankshaft. The cylinders lie on both sides outside the frames, and drive the intermediate shaft by means of connecting-rods and cranks. The upper axle carries a toothed brake-wheel with an arrangement to be used in case of an accident to the driving wheel. The ordinary brake works on the dises of the crankshaft.

When going down hill, an air counter-pressure brake is made use of, that is, the valve-gear is reversed and the regulator is

FIG. 57.-Strub System.:

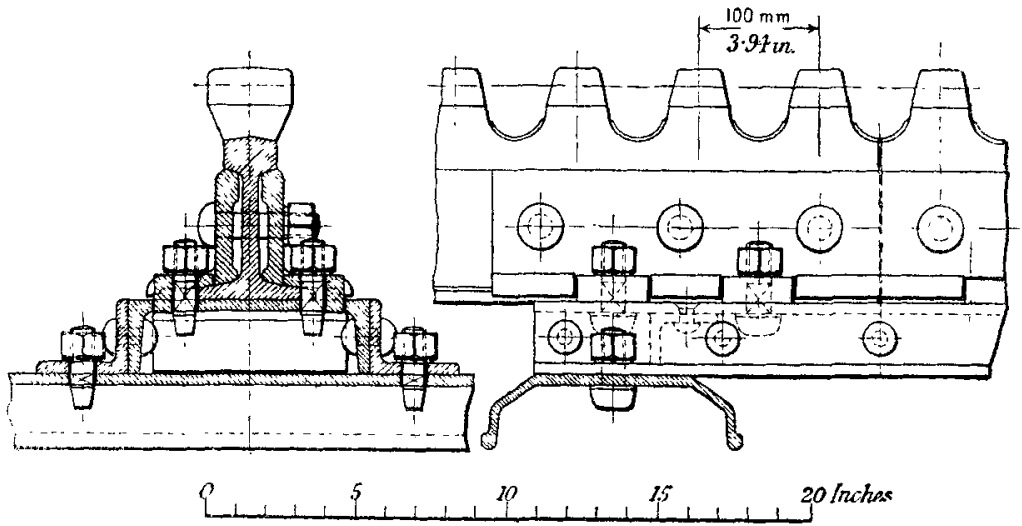

shut off. The pistons then draw air into the cylinder which is compressed up as far as the regulator. This braking is governed by throttling the exhaust of the compressed air by means of a valve worked by the driver.

In the latest locomotives of the Rigi Railway, Fig. 60 (page 548), which were built at the Winterthur Works between 1899 and 1902, the cylinders are placed farther toward the leading end. The driving cog-wheel, which is driven by means of gearing from the intermediate axle, has a larger diameter and is placed close behind the front carrying-axle; the trailing carrying-axle is provided with rack-brake. The brakes are arranged in the same manner as on the old engines, but in addition a centrifugal governor is made use 
of, which automatically controls the maximum speed, at which point a steam-brake is put into action. This automatic speed-regulator

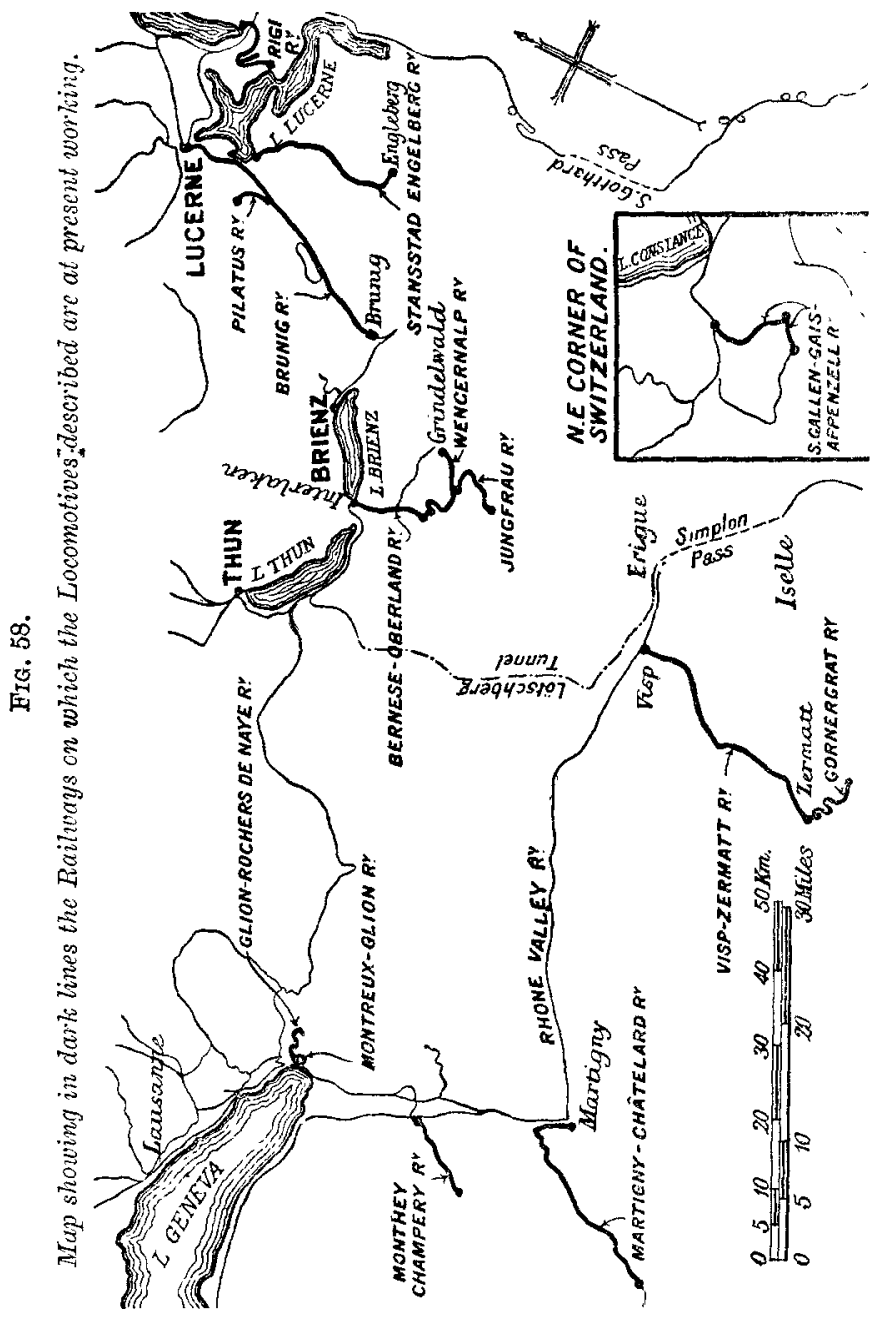

(a special construction of the Winterthur Works) has to be applied, by order of the Swiss Railway Department, on all rack-locomotives in service of Swiss lines. The speed of the Rigi locomotive is 
$2 \cdot 1$ metres $(6.8$ feet) per second $(4 \cdot 7$ miles per hour $)$, and the total weight of the train is between 25 to 28 tons, about 200 h.p. being developed by the engine.

\section{FrG. 59.-Rigi Railway.}

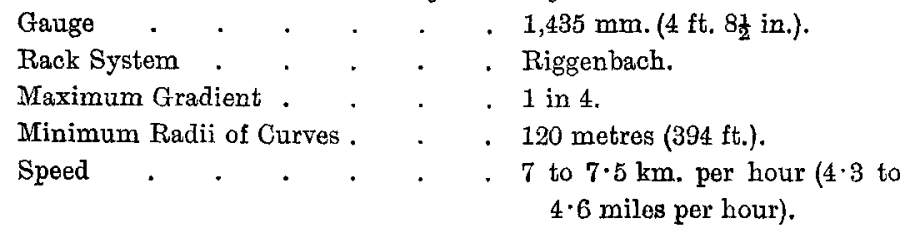

Tractive Power Maximum . . . $8,500 \mathrm{~kg} \cdot(8 \cdot 36$ tons $)$.

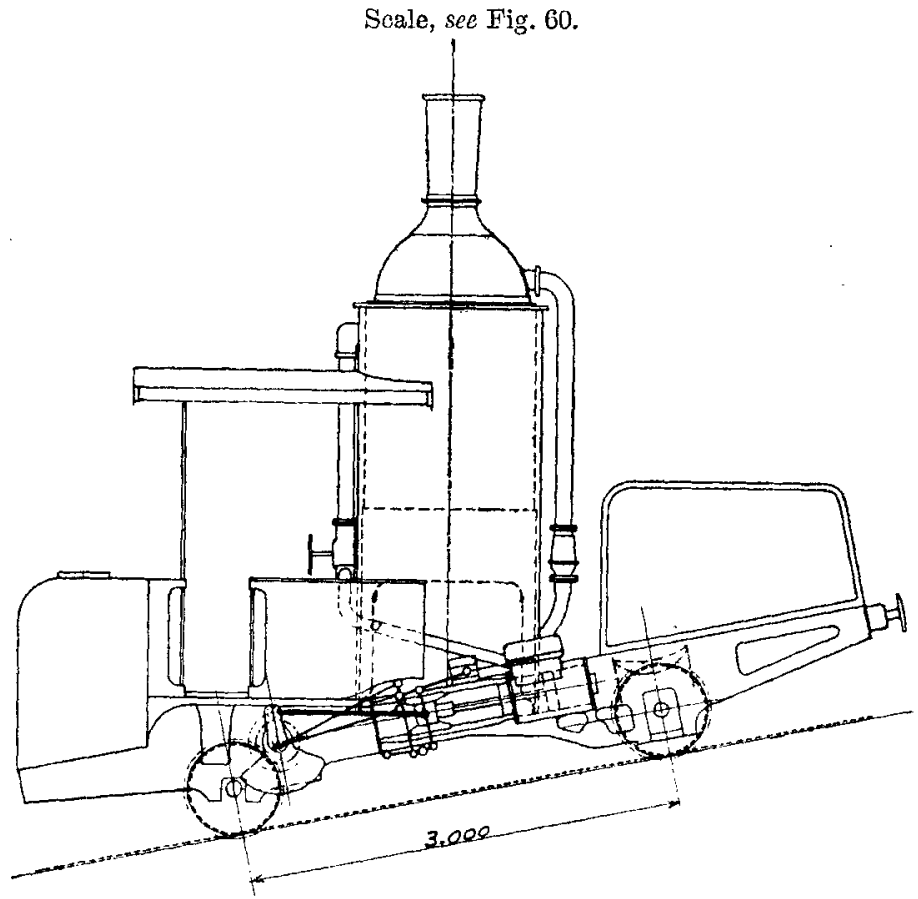

The Arth-Rigi Raitway was opened in 1875 , having a length of $9.8 \mathrm{~km}$. (6.1 miles) with 20 per cent. gradients, and has engines similar to those used on the Vitznau-Rigi Railway, which, however, is at present partially served by electricity. Also the RorschachHeiden Railway, with a length of $6.08 \mathrm{~km} .(3.8$ miles) and 9 per 
cent. maximum gradient with a total rise of $406 \mathrm{~m}$. (444 yards), has engines of the same pattern.

In June 1889, the Pilatus Railway, the steepest rack-railway in the world, was opened. It has a length of $4,610 \mathrm{~m}$. (2.86 miles), a total difference of level of $1,630 \cdot \mathrm{m} .(5,346$ feet $)$, gradients being

$$
\text { FıG. 60.--Rigi Railway. }
$$

\section{Gauge}

Rack System

Maximum Gradient .

Minimum Radii of Curves.

Speed

Tractive Power Maximum
. $1,435 \mathrm{~mm}$. ( $4 \mathrm{ft} .8 \frac{1}{2}$ in.).

- Riggenbach.

. 1 in 4 .

. 120 metres (394 ft.).

. 7 to $7.5 \mathrm{~km}$. per hour $(4 \cdot 3$ to $4 \cdot 7$ miles per hour).

- $8,500 \mathrm{~kg} \cdot(8 \cdot 36$ tons $)$.

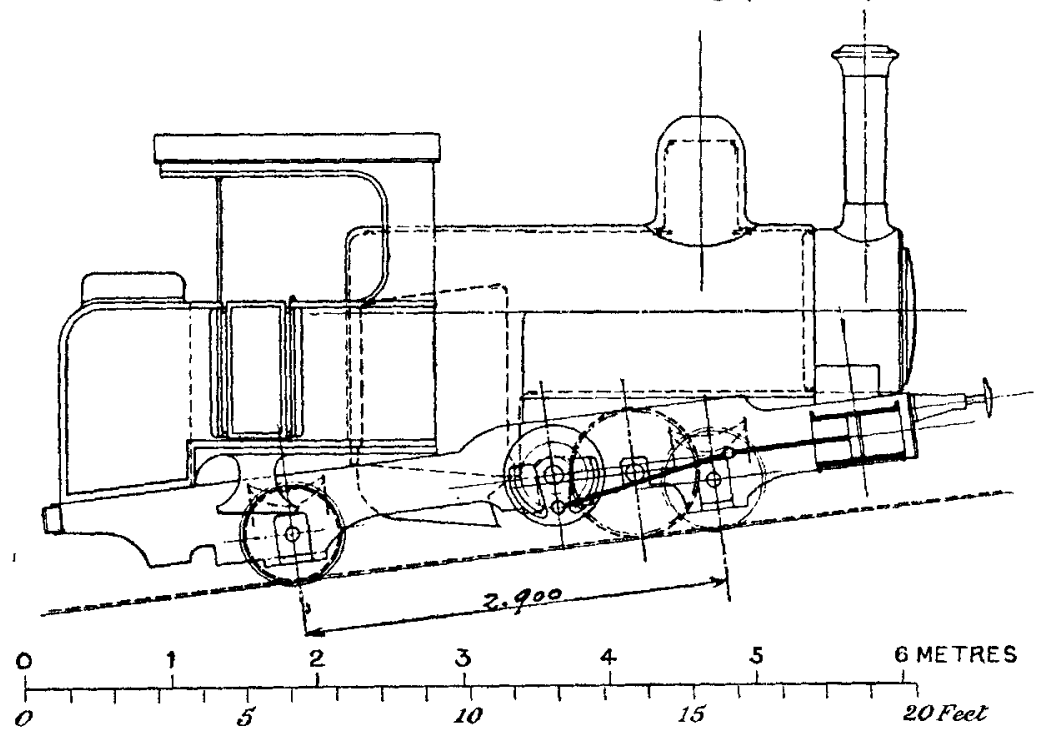

19.2 per cent. to 48 per cent., the mean gradient being 38.1 per cent. The road has $80 \mathrm{~cm}$. ( 2 feet $7 \frac{1}{2}$ inches) gauge. The rackgear is on Locher's system.

The locomotive carriage shown by Fig. 61 takes thirty-two passengers, the coach and locomotive all being combined in one vehicle. The underframe of the coach forms at the same time 
FIg. 61.-Pilatus Railway.

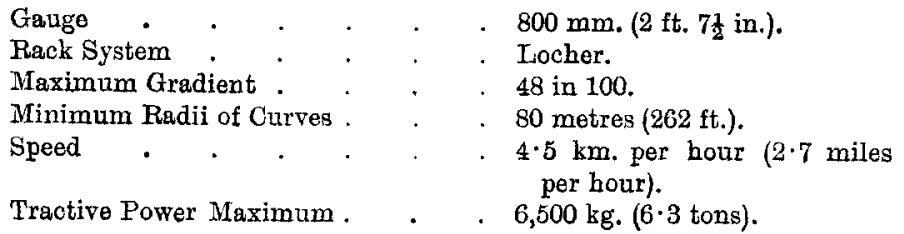

Scale, see Fig. 60.

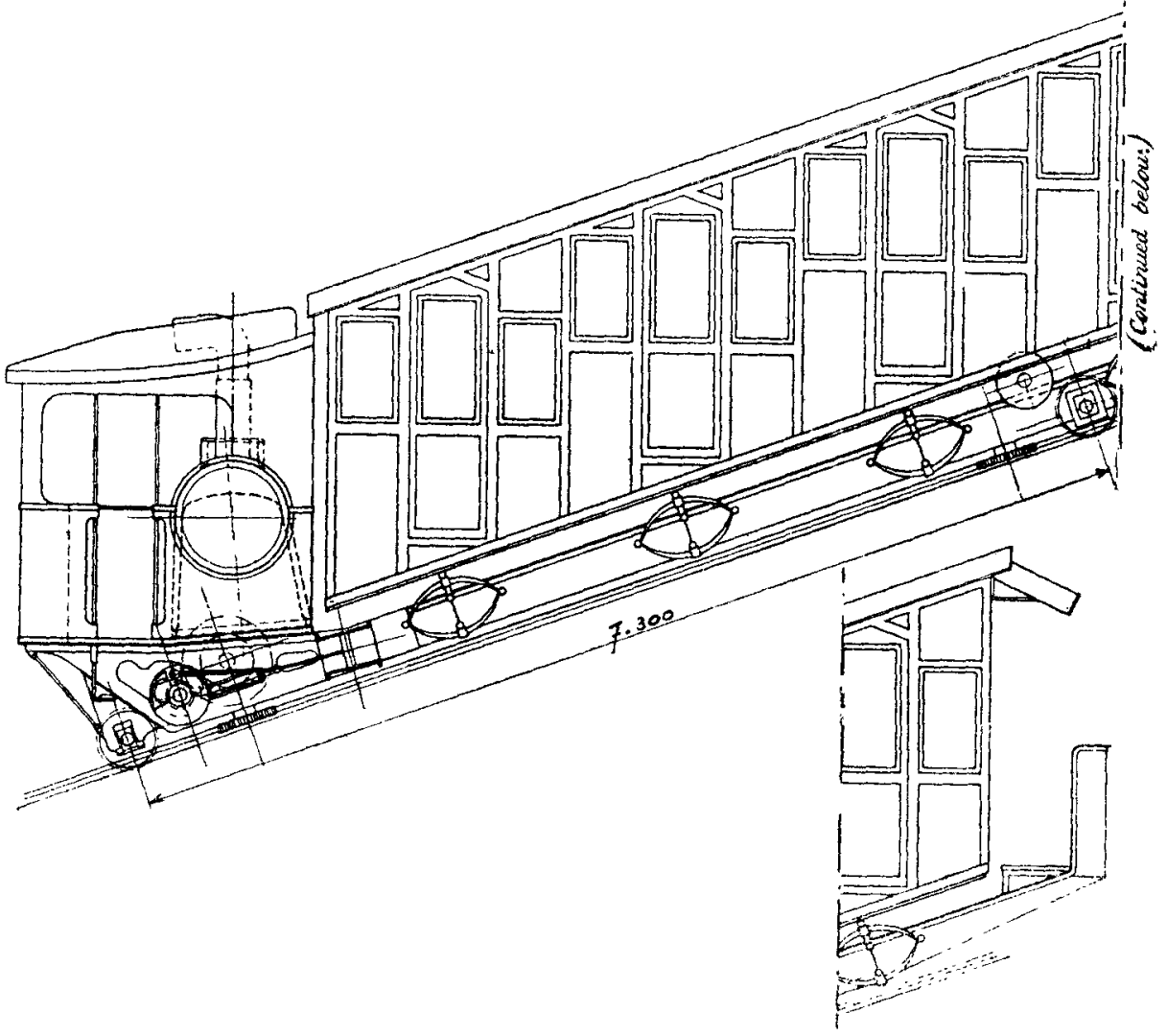

a tender containing 800 litres (176 gallons) of water. The carriage is carried on two axles on three points. The boiler is of the ordinary locomotive form, but on account of the varying gradients 
it is placed transversely to the rails. The cylinders drive by a spur-wheel gearing on an intermediate axle, from which the power is transmitted by two pairs of conical wheels on the two vertical driving axles. At the lower end of these driving-axles the driving-wheels are placed together with their guide-rollers in order to ensure that the wheels gear properly into the rack. The leading gear-wheel is only used for the purpose of a brake, and its rollers have to guide the carriage against the Vautrin rail. The leading toothed-wheels run freely when the coach is going up the inclines, and they are locked when running down hill by means of a coupling through which they transmit reverse motion to two symmetrical worm-wheels, their axle carrying the brake-dise. By reason of the high gear-ratio, relatively small braking-power is sufficient to bring the train to a standstill. The brake is automatically put on when the speed-limit is exceeded. The following brakes are arranged: An air-compression brake when running down the banks, a frictional brake on the crankshaft, as well as friction and self-acting brakes on the leading pair of geared wheels as already described. The normal speed of the train is 1.2 metre $(47 \cdot 24$ feet) per second $(2 \cdot 7$ miles per hour $)$, the weight of the combined engine and carriage is 12 tons, and the engine develops 100 h.p. Very excellent results have been obtained by the use of superheated steam.

The locomotive, Fig. 62, has been designed by Mr. Roman Abt and executed for Abt and Riggenbach rack-rail by the Winterthur Works.

The engine is a special type of rack-locomotive for narrow gauge, steep gradients and small curves. It is constructed with two driving and one Bissel axle. On the driving axles are keyed the cog-wheels with brake-discs. The carrying wheels are running loose. The steam-power is transmitted from the cylinders by means of connecting-rods and rocking-levers on the crank-axles. The boiler, of ordinary locomotive type, is so mounted on the frame that its axis corresponds with the medium gradient. This type of locomotive works on a gauge of $800 \mathrm{~mm}$. (2 feet $7 \frac{1}{2}$ inches), minimum radius of curves of $60 \mathrm{~m}$. (175 feet), and gradients up to 
25 per cent. It has been accepted on the following railways: Generoso-, Brienz-Rothorn and Glion-Rochers de Naye with Abt's rack-rail ; for Schynige Platte and Wengernalp with Riggenbach rackrail. These lines were built between 1890 and 1893 .

\section{Fig. 62.-Glion-Rochers de Naye Railway.}

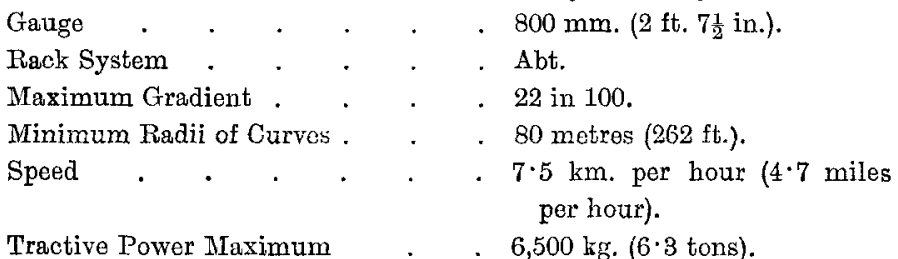

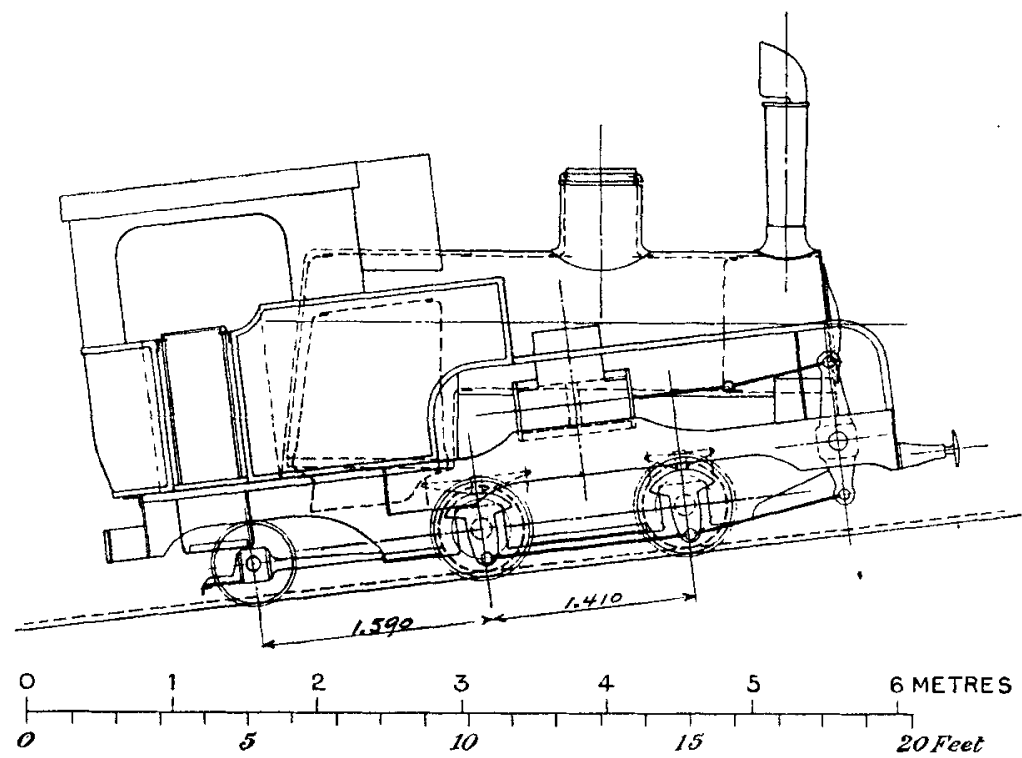

As the traffic on the Wengernaly Railuay (LanterbrunnenGrindelwald) increased (from year to year, heavier construction was asked for. In the year 1904 the Winterthur Works constructed a new type for this railway with a tractive power of about $11,000 \mathrm{~kg}$. (10:8 tons) against $6,500 \mathrm{~kg}$. $(6 \cdot 3$ tons) of the old type. The engine is built with three carrying-axles, the trailing one is a 
Bissel axle, Fig. 63. The steam power is transmitted in the ordinary way by means of two intermediate crankshafts on two rack-driving axles. A special construction regulates the equal division of the

Fig. 63.-Wengernalp Railway.

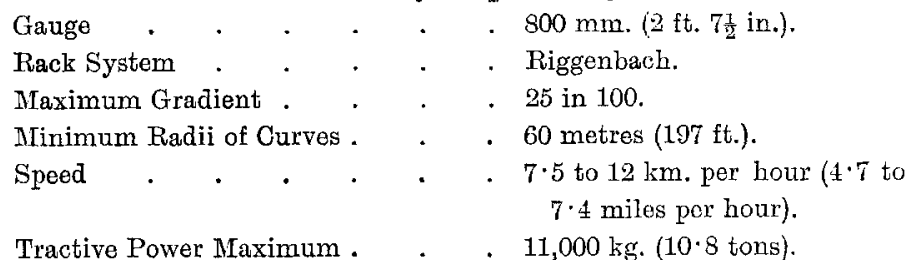

Scale, see Fig. 64.

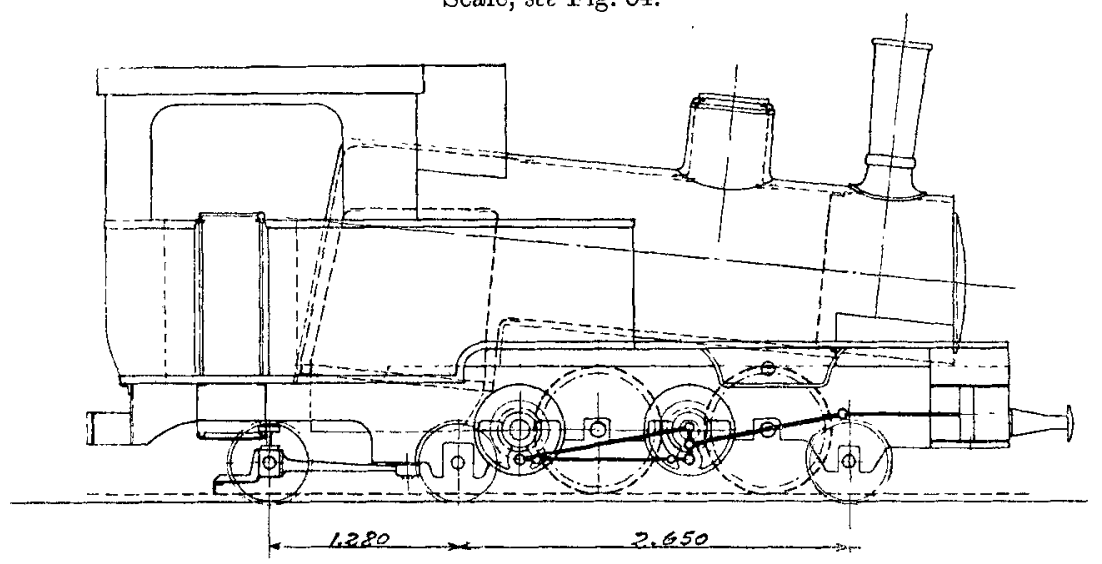

tooth-pressure on both cog-wheels. The brake arrangements of all these engines are the same as those on the Rigi locomotive.

(b) Locomotives for Rack and Adhesion Driving.-. In the year 1888 the first line for adhesion and rack-gear service had been opened with the Brünig Reilway, constructed by the Jura-Berne Lucerne Railway Company, now belonging to the Swiss State Railway.

The Brünig Railway is divided into three parts, of which the lengths between Brienz-Meiringen and between Giswyl and Lucerne are worked by adhesion, but the length of $9,013 \mathrm{~m}$. (5.6 miles), having a maximum gradient of 12 per cent., is fitted with the Riggenbach rack. The total length of the line is $56.37 \mathrm{~km}$. 
( 35 miles), the normal radius of the curves is $150 \mathrm{~m}$. (490 feet) and the sharpest curve is $90 \mathrm{~m}$. (295 feet).

The original engines have two driving axles for adhesion, two

FIG. 64.-Swiss Confederation Railways (Brimig Railway).

Gauge . . . . . . $1,000 \mathrm{~mm}$. (3 ft. $3 \frac{3}{6}$ in.).

Rack System . . . . . . Riggenbach.

Maximum Gradient . . . . 12 in 100.

Minimum Radii of Curves . . $\quad$. 90 metres (295 ft.).

Speeds . . . . . . 12 and $45 \mathrm{~km}$. per hour $(7 \cdot 4$ to 28 miles per hour).

Tractive Power Maximum . . . $11,000 \mathrm{~kg} .(10 \cdot 8$ tons $)$.

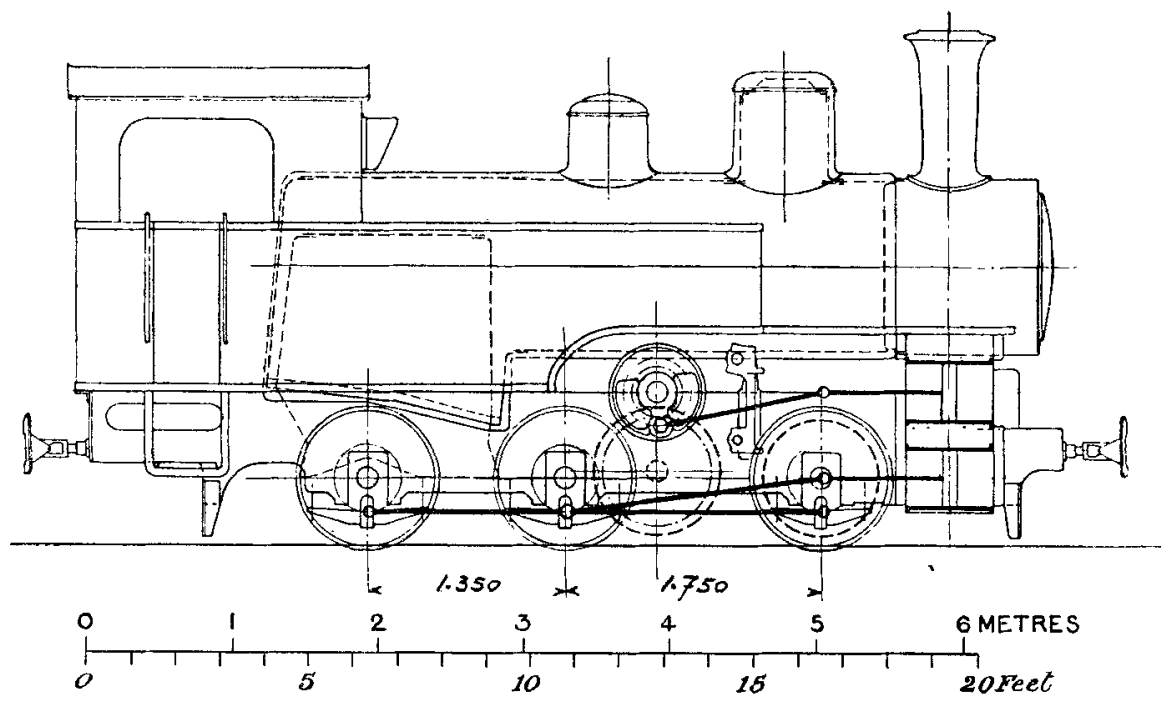

cylinders and rigid coupling between the adhesion and the rack-gear mechanism. The cylinders are placed between the frames below the smoke-box and drive by means of the intermediate shaft and a spur-wheel gearing on the rack driving-wheel, which is coupled by a special design of coupling-rods to the adhesion axles.

A new locomotive for this line, the "Winterthur" type, was designed in the year 1905, which is shown on Fig. 64. This locomotive is constructed as a four-cylinder compound engine, 
the cylinders being placed by couples outside the frame as well as their driving gears, so that the maintenance and repairing of all parts is rendered easy. The lower cylinders are the high-pressure cylinders and work as a twin engine on the adhesion mechanism, while the rack-gear mechanism, driven by the upper, viz, the lowpressure cylinders, is stopped, the steam exhaust going from the high-pressure cylinders directly to the exhaust-pipe. As soon as the locomotive enters the rack, the drivers change the direction of the high-pressure exhaust by means of two steam-manipulated valves; the low-pressure cylinders and the rack-gear mechanism begin also to work. Generally the four cylinders have the same dimensions, and the relation of their volume for good steam-compounding is obtained by the relative dimensions of the intermediate spur-wheel gear of the low-pressure mechanism, namely, by the relation of the number of revolutions of the two mechanisms. The following brakes are provided: One hand-brake having four blocks on the trailing adhesion-axle; a band-brake acting on dises on the intermediate crankshaft. An emergency braked gear-wheel, which is carried loosely on the leading adhesion-axle, and an air-repression brake are provided for going down hill. The locomotive is also arranged with Westinghouse brakes for acting directly on the train.

The Bernese-Oberland Railway was opened in 1890, has a gauge of $1 \mathrm{~m} .(3 \cdot 28 \mathrm{feet})$, and the rack is of the ladder form. The length of the line is $23 \cdot 446 \mathrm{~km}$. $(14 \cdot 35$ miles), out of which $4,978 \mathrm{~m}$. (3 miles) are fitted with the rack. The differences in levels are as follows:-Between Interlaken and Lauterbrunnen $229 \mathrm{~m}$. (752 feet), Interlaken and Grindelwald $467 \mathrm{~m}$. (1,532 feet). The gradients for the first line are 9 per cent. and for the latter 12 per cent. The maximum gradients where adhesion is used are 2.5 per cent. The original locomotives, Fig. 65 (page 555), are six-coupled, four-cylinder twin tank-engines with separate driving gear for the adhesion and for the rack working. The inner pair of cylinders drives on an intermediate shaft with pinion gearing directly in the toothed driving rack-wheel. A loose braking rack-wheel is placed on the first adhesion axle. Each pair of cylinders has a separate regulator, but both of them are manipulated by means of 
one controlling screw. Both the rack and the adhesion mechanism are controlled by an air-repression brake, in addition to which both rack-wheels are also provided with separate hand-brakes. The third

\section{FIG. 65.-Bernese-Oberland Railway.}

Gauge . . . . . . 1,000 mm. (3 ft. $3 \frac{3}{8}$ in.).

Rack System . . . . . Riggenbach.

Maximum Gradient . . . . 12 in 100.

Minimum Radii of Curves . . . 80 metres $\left(262 \frac{1}{\mathrm{ft}}\right.$.).

Speeds . . . . . . 12 and $35 \mathrm{~km}$. per hour $(7 \cdot 4$ to $21 \cdot 7$ miles per hour).

Tractive Power Maximum . . . 10,000 kg. (9.8 tons).
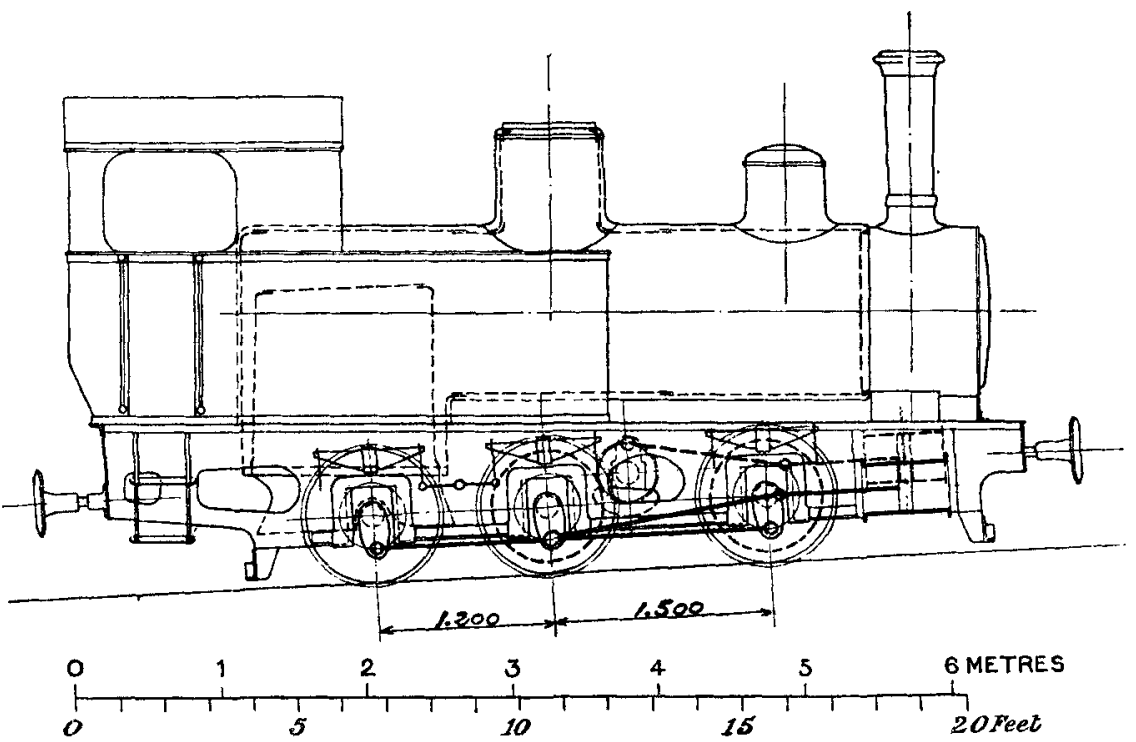

hand-brake, which acts on all adhesion driving-wheels, is chiefly used as a shunting brake. Further, the engine is provided with a Klose continuous steam-brake for braking the train itself.

In the year 1906 the Bernese-Oberland Railway ordered two new locomotives of the "Winterthur" type, equal to those of the Brünig, shown on Fig. 64. At the present time they are providing their boilers with Schmidt's superheater. 
In 1890 the only mixed system of railway mounted on the public road was built between St. Gallen and Gais. The gauge is $1 \mathrm{~m}$. In a total distance of $19 \cdot 52 \mathrm{~km} .(12 \cdot 12$ miles $) 15 \cdot 1 \mathrm{~km} .(9 \cdot 4$ miles $)$ are built on the ordinary high road. Twenty-six per cent. of the line have gradients above 4 per cent. and are provided with Klose's system of rack. The steepest gradient is 9.2 per cent, and the smallest curve has 30 metres radius.

The first locomotives of this line were built between 1889 and 1891, according to the Klose system, shown on Fig. 66 (page 557). The engine has four-coupled adhesion-wheels, as well as a Bissel trailing bogie which carries the tank. The Bissel bogie axle is provided with a brake rack-wheel. The four adhesion-wheels are driven by two outside-cylinders. They are constructed as Klose's radial axles, that is to say, axles which can accommodate themselves to the curves, so they are fitted with the whole complicated mechanism necessary to do this. The rack-wheel is driven by two inside cylinders by means of an intermediate shaft and pinion which gears directly in it. The adhesion-engine works compound in connection with the engine driving the rack. This arrangement was designed by Klose.

The new engines of the St. Gallen-Gais line are of the "Winterthur" type, shown by Fig. 67 (page 557). They have four-coupled adhesion-wheels, the rack driving-wheel being placed between them. They have also leading and trailing two-wheel bogies. In other particulars these locomotives are similar to the new Brünig locomotives, Fig. 64.

The Visp-Zermatt Railway has also 1-metre gauge, is $35 \mathrm{~km}$. ( $21 \frac{3}{4}$ miles) long, rises $955 \mathrm{~m}$. (3,132 feet), and has 100-metre (328 feet) minimum curves, where the gear is in use. There are six sections having rack-rails on the Abt system, with a total length of $7 \cdot 2 \mathrm{~km}$. ( $4 \frac{1}{2}$ miles). The heaviest gradient on the rack is $12 \frac{1}{2}$ per cent. The remaining five heavy gradients are only 10 per cent. The adhesion-sections have a maximum gradient of $2 \frac{1}{2}$ per cent., and are arranged with curves of a minimum radius of $80 \mathrm{~m}$. (262 feet). The locomotives draw the trains.

The engines shown on Fig. 68 (page 558) are combined fourcylinder twin engines on the Abt system. The cylinders driving the 
Figs. 66 and 67.-St. Gallen-Gais-Appenzell Railway.

Gauge

Rack System

Maximum Gradient

Minimum Radii of Curves.

Speeds

Tractive Power Maximum .
1,000 mm. (3 ft. $3 \frac{3}{8}$ in.).

Klose.

23 in 250.

30 metres $\left(98 \frac{1}{2} \mathrm{ft}\right.$.).

- 12 and $30 \mathrm{~km}$. per hour (7-4 and

$18 \cdot 6$ miles per hour).

. $10,000 \mathrm{~kg} .(9 \cdot 8$ tons $)$.

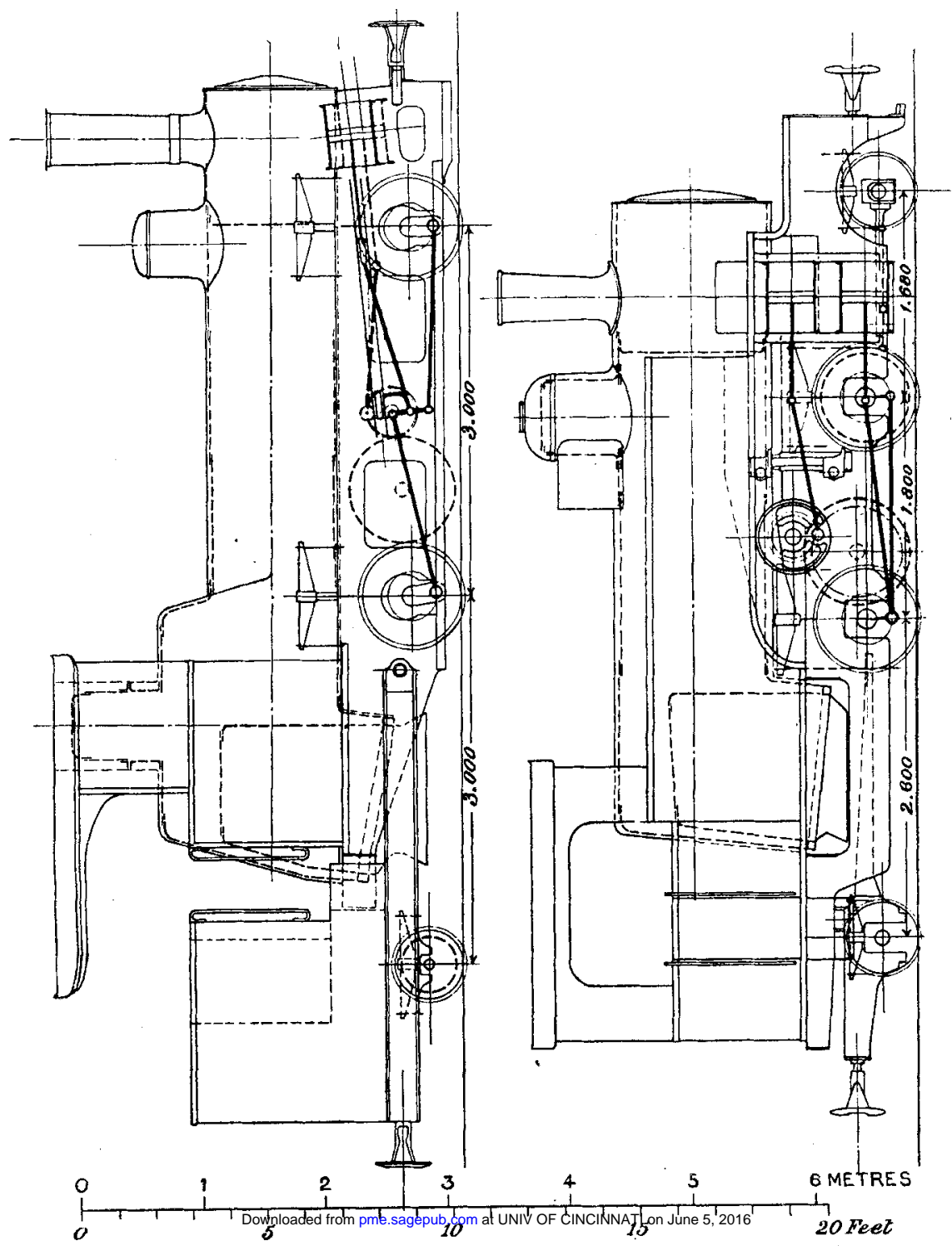


adhesion-wheels are placel outside, those driving the rack-gear are placed insile. The two rack driving-wheels are mounted in a FIG. 68.-Tisp-Zermatt Railway.

\begin{tabular}{|c|c|c|c|c|c|}
\hline Gauge & . & . & ${ }^{\circ}$ & , & . $1,000 \mathrm{~mm}$. ( $\left.3 \mathrm{ft} .3 \frac{3}{\mathrm{~s}} \mathrm{in}.\right)$. \\
\hline Rack Syst & em & . & & & . Abt. \\
\hline Maximum & Gradient & . & . & & 12 in 100. \\
\hline Minimum & Radii of $\mathrm{C}$ & Curves & . & . & . 80 metres ( $262 \frac{\mathrm{T}}{2} \mathrm{ft}$.). \\
\hline Speeds & . $\quad$. & - & . & 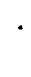 & $\begin{array}{c}12 \text { and } 30 \mathrm{~km} \text {. per hour }(7 \cdot 4 \\
\text { and } 18.6 \text { miles per hour })\end{array}$ \\
\hline Lractive $\mathrm{P}$ & wer Ma & & & & . $10,500 \mathrm{~kg} \cdot(10 \cdot 3$ tons $)$ \\
\hline
\end{tabular}

Scale, see Fig. 69.

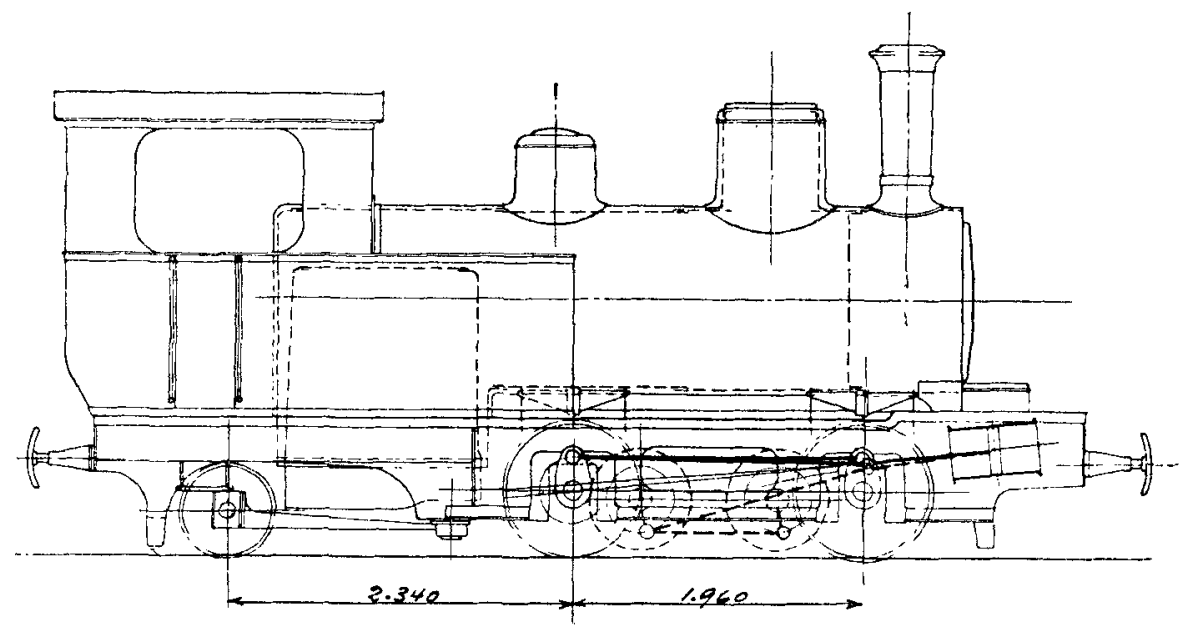

separate frame suspended on the two driving adhesion-axles, and so they are independent of the play of the springs, according to the Abt system. There is a Bissel bogie underneath the driver's foot-plate which ensures the engine taking curves properly.

The small engine, shown in Fig. 69 (page 559), is used for an easy traffic and serves also as a contractors' locomotive for construction of rack railways. On the mean gradient the boiler is level.

The frames are carried by two adhesion-axles which are connected by means of connecting-rods with the rack driving-wheel placed between them. One of the adhesion-axles carries a loose rack 
brake-wheel. The cylinders placed between the frames drive by an intermediate crank-axle with pinion and spur-wheel on

Fig. 69.-Martigny-Châtelard Railway.

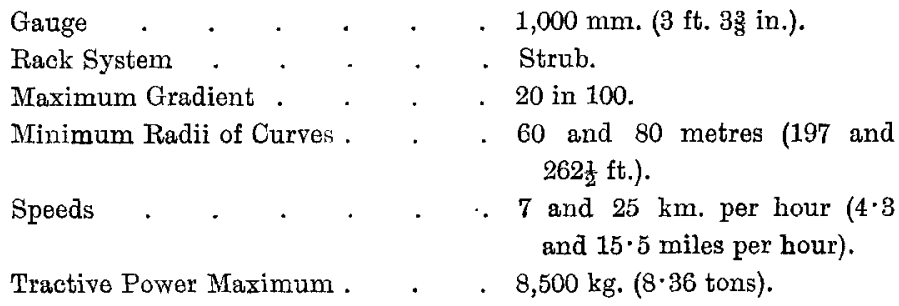

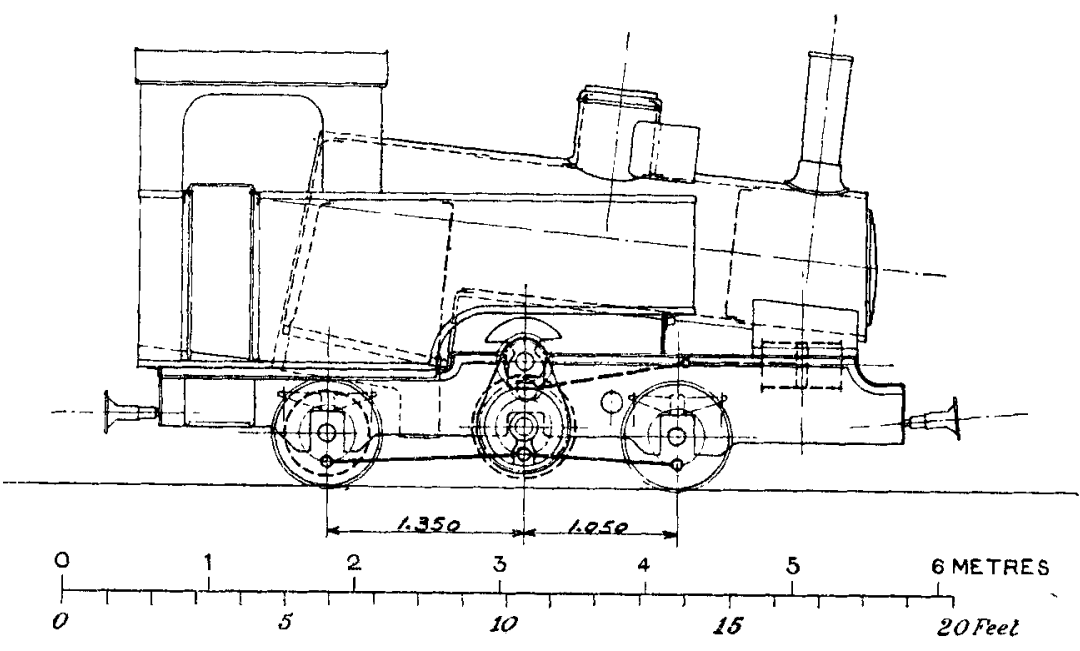

the rack-wheel axle just as described for the first Brünig locomotive.

\section{ELEC'RIC Locomotives.}

The very great improvements made in electrical traction were naturally utilized to carry on also the working of rack-railways. The Gornergrat line, which starts from the terminus of the Visp-Zermatt railway was the first rack-railway to use electricity, and afterwards a whole series of other railways followed this example. 
(a) Raitways on Rack only.-The Gornergrat line was opened in 1898, the gauge is 1 metre, the rack is on the Abt system, it has FIG. 70.-Gornergrat Railway.

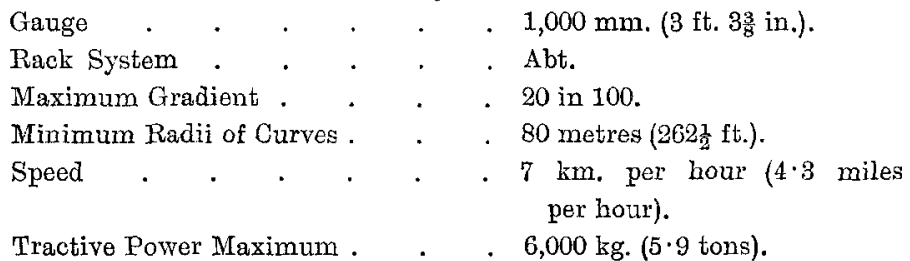

Scale, see Fig. 71.

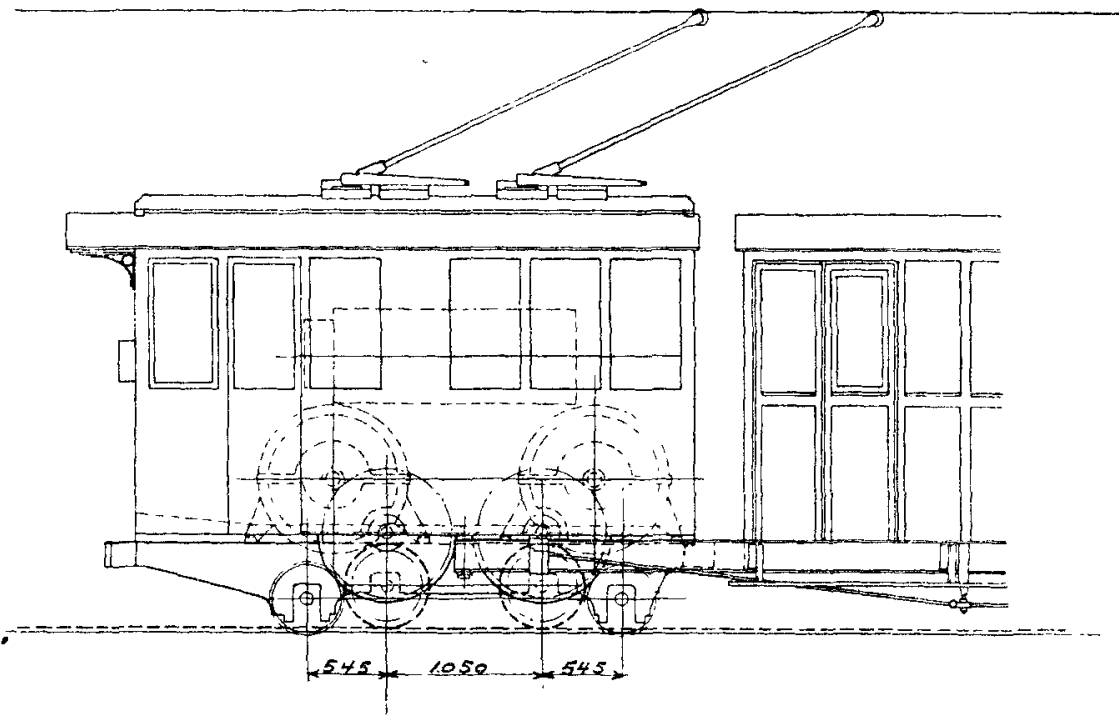

a length of $9,346 \mathrm{~m}$. (5.8 miles), and ascends a height of $2,359 \mathrm{~m}$. (7,740 feet). The maximum gradient is 20 per cent., and the smallest curves are $80 \mathrm{~m}$. (2621 feet). The locomotive is shown in Fig. 70, and is provided with two polyphase motors, each having a maximum output of 90 h.p. at 800 revolutions a minute with 500 volts pressure. The motion is conveyed to two independent rack driving-wheels by means of an intermediate shaft and double spur-wheel gearing. The locomotives rest on two carrying axles having springs with a definitely controlled range. The passenger 
coach is suspended to the locomotive frame in accordance with $\mathrm{Mr}$. Rowan's design. By this construction a part of the coach's load increases the weight of the locomotive and so ensures the rack-wheels from riding. The engine is fitted with two hand-brakes, each of which acts on both driving rack-wheels, and an automatic brake working on the rotor-axles. This brake can be manipulated also by hand, either by the engine-driver or by the conductor in charge of the train. When the train is going down hill the motors act as generators; the current which is then developed goes up by means of the bows back into the central station, where it tends to reduce the load.

One month after the Gornergrat Railway was opened the first part of the Jungfrau Railway was also started. The part between "Kleine Scheidegg" and "Eismeer" has a difference in level of $1,092 \mathrm{~m}$. (3,580 feet), and it was opened in 1905. The length is $5.8 \mathrm{~km}$. $(3 \cdot 6$ miles $)$ and the gradient is generally 25 per cent. The gauge of the line is 1 metre. Where the line is in the open cutting the curves have a radius of $100 \mathrm{~m}$. (328 feet), the curves in the tunnel having $200 \mathrm{~m}$. (656 feet) and the curves leading into the points $80 \mathrm{~m}$. (2621 feet). Strub's rack was first applied here and three-phase current used.

The locomotive shown on Fig. 71 (page 562) is of the same construction as the Gornergrat locomotive, its performance being somewhat higher. The speed of the train is $7 \cdot 5 \mathrm{~km}$. (4.65 miles) an hour. When running down hill the braking is controlled by means of an electric resistance which is cooled by a fan. The motors then work as ordinary generators owing to a special change in their connections, and the current thus generated is transformed into heat.

In the years 1900 and 1901 the Aigle-Leysin and Bex-GryonVillars Railway had been opened as the first rack-railways with continuous-current. The gauge is 1 metre, gradients from 9 to 23 per cent.; minimum curves 60 metres radius. The rack is on the Abt system. The locomotives are fitted with two driving and a brake rack-wheel. With these engines the Winterthur Locomotive Works pattern of friction-disc coupling was first applied. It 
serves to reduce shocks resulting from short-circuiting and those coming from irregularities of the rack-pitch.

Fra. 71.-Jungfrau Railway.

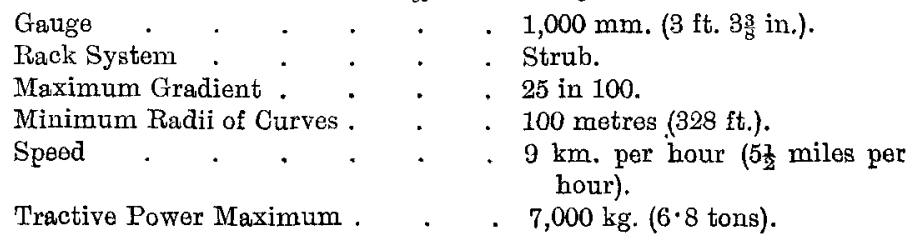

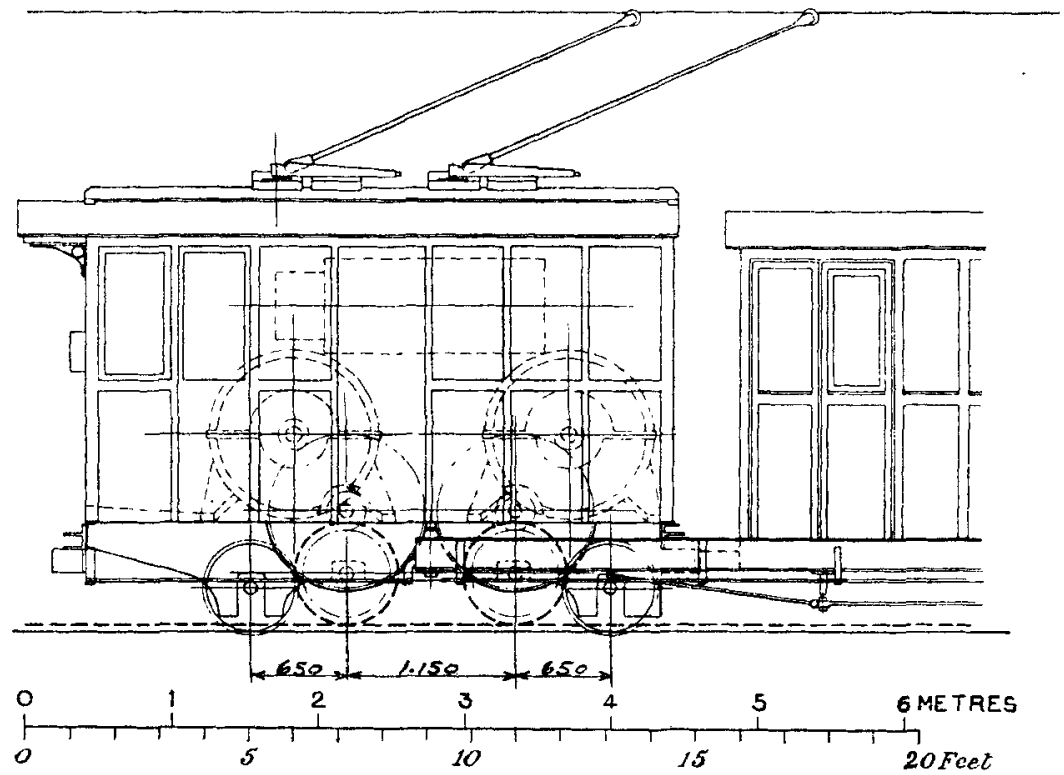

The Brunnen-Morschach Railway on the Vierwaldstätter See was opened in the year 1905 . The line is $2.05 \mathrm{~km}$. ( $1 \frac{1}{4}$ miles) long, the mean gradient being $12 \cdot 6$ per cent., the maximum gradient 17 per cent. The line rises $257 \mathrm{~m}$. ( 842 feet), and the curves are $80 \mathrm{~m}$. (262 feet) radius. Strub's rack-gear was used in this case. The locomotives are connected to the coaches on Rowan's system. These engines have only one single driving-wheel, driven by two polyphase motors, each of 80 h.p., by means of double transmitting gear. The trailing carrying-nxle is provided with a 
brake rack-wheel, and it and the driving rack-wheel are both braked. On both the up and down journeys a safety grip is used,

Fig. 72.-Wengernalp Railway.

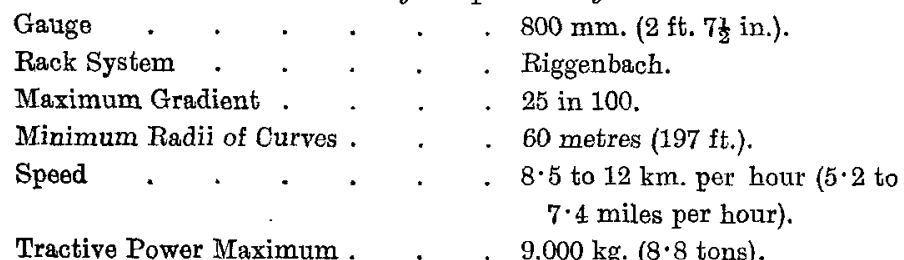

$9,000 \mathrm{~kg} \cdot(8 \cdot 8$ tons $)$

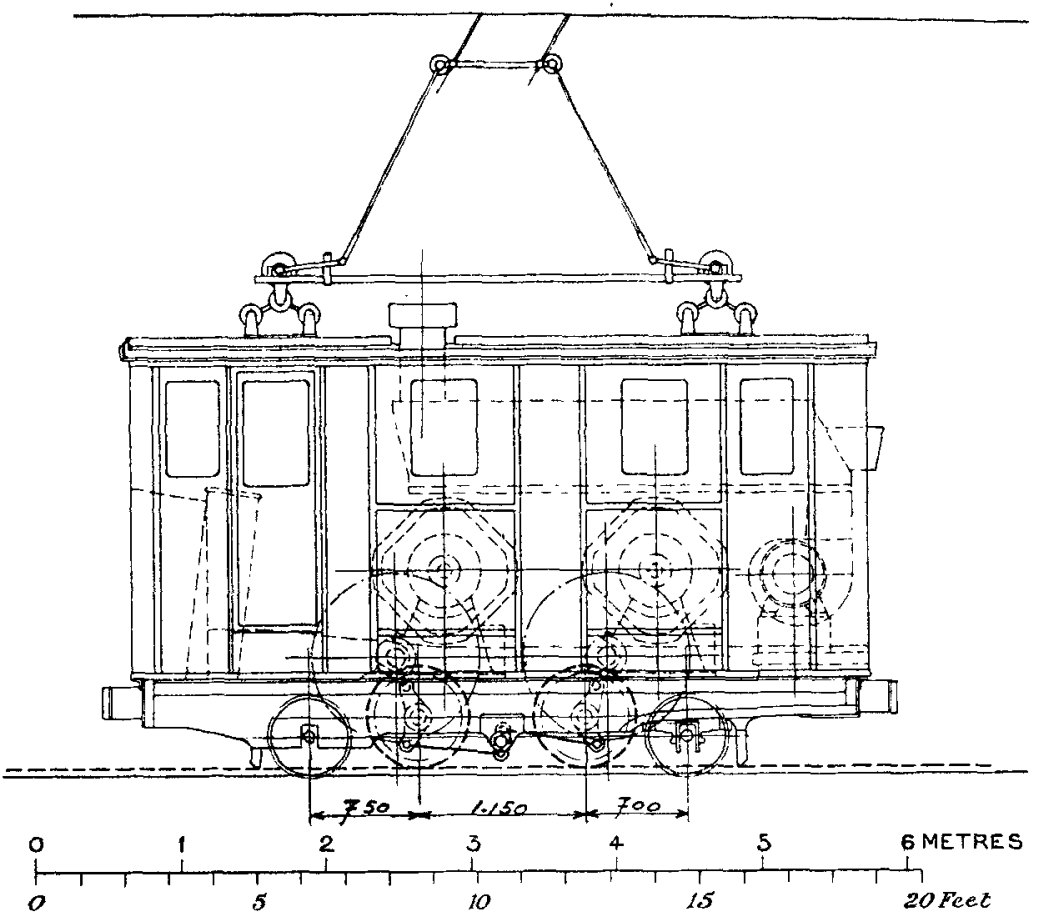

in addition to which the brake-wheels are fitted with! guide-flanges in order to provide for greater security against the wheels mounting the rails.

The Wengernalp Railway commenced to use electric driving 
in June 1909, and now has ten locomotives of 300 h.p. each. These engines, shown on Fig. 72 (page 564), are generally of the same construction as those of Gornergrat and Jungfrau. It is to be noticed that up to now they are the only ones built for $800 \mathrm{~mm}$. ( 2 feet $7 \frac{1}{2}$ inches) gauge, which presents great difficulties in arranging for the transmission of power and the arrangement of the brakes. They have an equalization of pressure on the rack-wheels arranged by means of balancing levers. This arrangement has been adopted by the Swiss Locomotive Works, as well as a system of automatic interlocking which prevents the automatic brakes from being put in action when the train is going uphill.

Each locomotive is provided with two-series continuous-current motors, each of 150 h.p., this full power being capable of continuous use. The motor makes 750 revolutions per minute, and they are worked in series by bow-contacts at 1,500 to 1,800 volts. The braking when running down hill is done by the ordinary method of short-circuiting.

(b) Mixed Rack and Adhesion Lines-The Stansstad-Engelberg line was opened in the year 1898, and has a length of $22.5 \mathrm{~km}$. (14 miles). It is driven by three-phase current of 750 volts. The gauge is 1 metre, and for a length of $1 \frac{1}{2} \mathrm{~km}$. (4,920 feet) the ladder form of rack-rail is used. The total ascent is $564 \mathrm{~m}$. (1,850 feet), and it is worked by adhesion up to 5 per cent. gradients; the steepest rack line gradient is 25 per cent.

The two motors of the engine, which is shown on Fig. 73, develop 150 h.p. each, and work by means of " $V$ " gearing and an intermediate shaft to the only rack driving-wheel. A special construction of a friction switch (made by the Winterthur Locomotive Works) permits the two carrying axles engaging as driving axles on the adhesion lines by means of coupling-rods.

The Martigny-Chatelard Railway was opened in the year 1904. It is $19 \cdot 132 \mathrm{~km}$. (11.9 miles) long, is provided with a Strub rack-

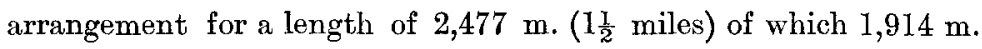
$(1.2$ mile) have a gradient of 20 per cent. The adhesion part of the line has gradients up to 7 per cent., and the smallest curves have a radius of $25 \mathrm{~m}$. (82 feet). The locomotives of this line are worked 
by continuous current. Their general construction is the same as those of the Jungfrau Railway, but independent of the carriage.

\section{FIG. 73.-Stansstad-Engelberg Railway.}

\begin{tabular}{|c|c|c|c|c|c|}
\hline Gauge & . & . & . & & . $1,000 \mathrm{~mm}$. (3 ft. $38 \mathrm{in}$.$) .$ \\
\hline Rack Sys & tem & . & . & & Riggenbach. \\
\hline Maximun & Gradient & & . & & . 25 in 100 \\
\hline Minimum & Radii of $\mathrm{C}$ & Jurves & . & & . 50 metres (164t ft.). \\
\hline Speeds & . $\quad$. & · & • & & $\begin{array}{r}5.5 \text { and } 11.5 \mathrm{~km} \text {. per hour } \\
(3.4 \text { and } 7.1 \text { miles per hour }) .\end{array}$ \\
\hline
\end{tabular}

Scale, see Fig. 72.

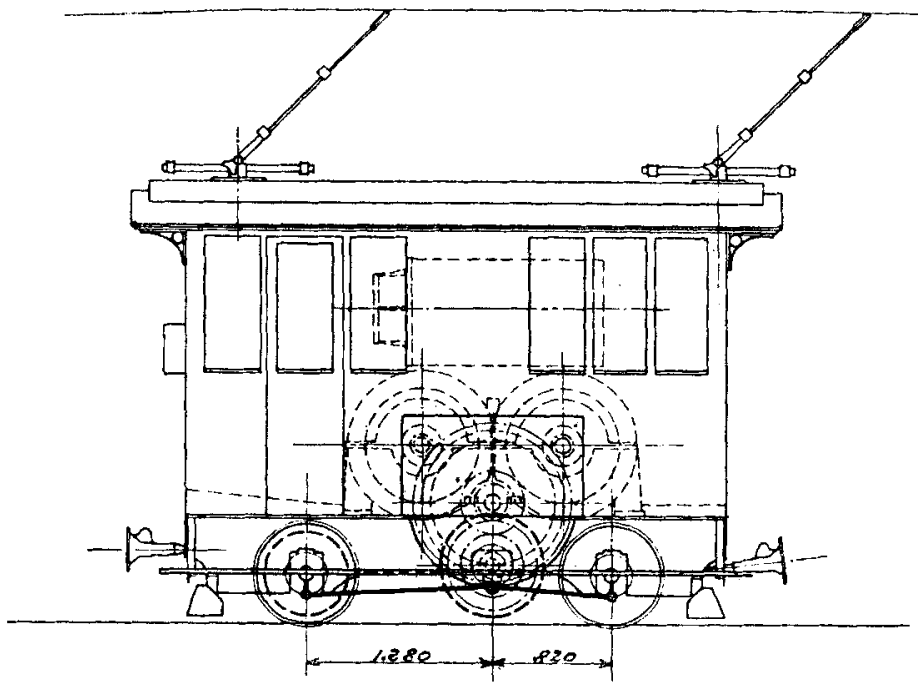

As these engines have to serve also on adhesion lines until 7 per cent. gradients they are provided with a rigid coupling by means of connecting-rods between rack-driving axles and carrying axles. The locomotive is equipped with the differential Westinghouse brake.

In addition to the locomotives there are on the MartignyChatelard line also nine motor-carriages, each of which rests on two four-wheel bogies. Each bogie has two motors of 80 to 100 h.p. which, by means of spur-wheel gearing and intermediate shaft, transmit the power on the rack as well as on the adhesion-axles. 
This rigid connection between adhesion and rack-wheels is not to be recommended, but up to date the system has worked without any interruption.

FIG. 74.--Montreux-Glion Railway.

\begin{tabular}{|c|c|c|c|c|c|c|}
\hline Gruge & . & - & , & - & . & . $800 \mathrm{~mm}$. ( $2 \mathrm{ft} .7 \frac{1}{2}$ in.). \\
\hline Rack Syste & tern & . & . & & $\cdot$ & Abt. \\
\hline Maximum & G Grar & dient & & & $\cdot$ & 13 in 100 . \\
\hline Minimum & Radi & ii of $\mathrm{C}$ & Jurves & . & . & . 60 metres (197 ft.). \\
\hline Speeds & $\cdot$ & . & . & . & . & $\begin{array}{l}10 \text { and } 15 \mathrm{~km} \text {. per hour }(6 \cdot 2 \\
\text { and } 9 \cdot 3 \text { miles per hour }) \text {. }\end{array}$ \\
\hline Tract & per & & & & & . $6,000 \mathrm{~kg} .(5 \cdot 9$ tons $)$ \\
\hline
\end{tabular}

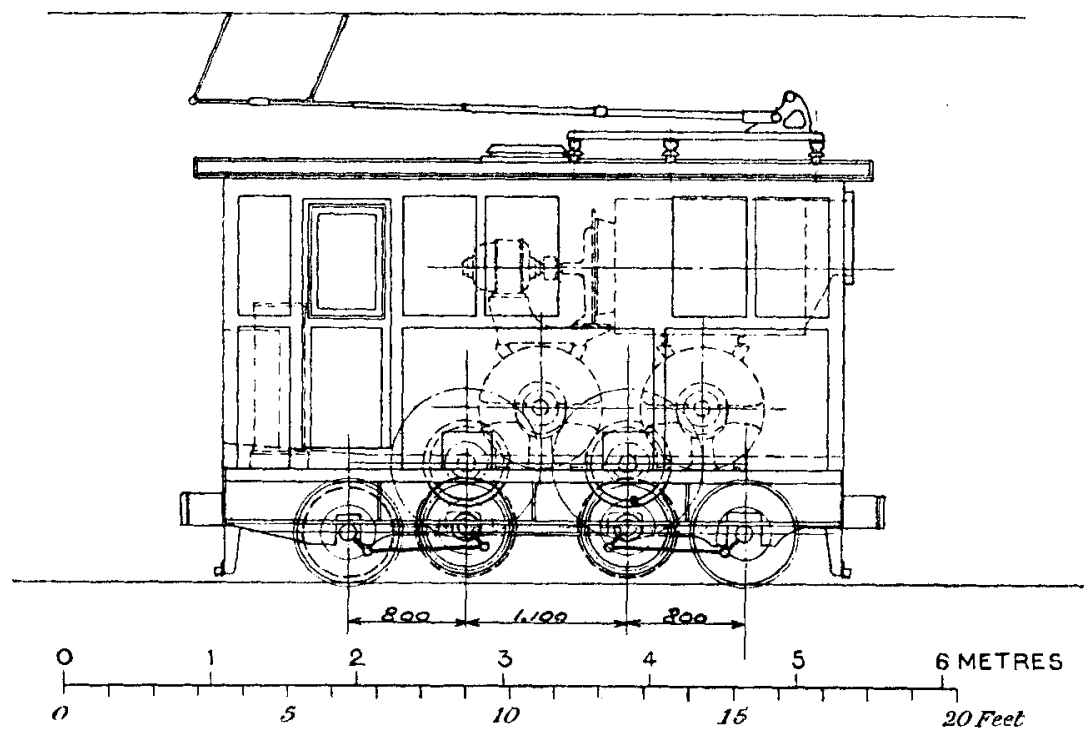

The line between Monthey and Champéry was opened in 1906, and has a length of $11.4 \mathrm{~km}$. ( 7 miles), having three heavy banks of 13 per cent. up to $13 \cdot 6$ per cent. It rises a total height of $640 \mathrm{~m}$. (398 feet). The gauge of the line is 1 metre, it is fitted with Strub rack-gear, having curves of $80 \mathrm{~m}$. (49.7 feet) radius, and is worked by means of a mixed system of motor coaches shown on Fig. 75 (page 568). The parts of the line that are worked by adhesion have maximum gradients of 5 per cent. and curves of 
$60 \mathrm{~m} .(37 \cdot 3$ feet). On this line two-bogie motor-cars are in service. The bogies, each of which has one adhesion and one rack-wheel driving motor, each independent of the other, allow varying gradients to be worked in the most efficient manner by the rolling stock. The adhesion-axles are driven by the adhesion motor and connected by coupling-rods. The rack-wheel motor works by means of double spur-gear on a rack driving-wheel mounted loose on one of the adhesion-axles.

In order to make the direct communication of the steam rack-railway between Glion-Rochers de Naye, which starts from the upper end of the Territet-Glion rope railway above Montreux, the Montreux-Glion line was built in the year 1909; it has a gauge of $800 \mathrm{~mm}$. (2 feet $7 \frac{1}{2}$ inches) and the Abt doubleflitch rack which was used in order that it might form a direct communication between Montreux and Rochers de Naye. The line has a total length of $2.8 \mathrm{~km}$. (13 mile) and rises $300 \mathrm{~m}$. (984 feet), the maximum gradient being 13 per cent. The radii of the curves are $80 \mathrm{~m}$. (262 feet) in the open part of the line, $60 \mathrm{~m}$. (197 feet) in the railway station, and $50 \mathrm{~m}$. (164 feet) at the points.

The locomotives shown on Fig. 74 (page 566) are arranged so that they can run either by adhesion or by the rack gear only. The two rack driving-axles are eash connected to the neighbouring adhesionaxles and carry a loose rack brake-wheel. The rack-wheels are always in motion as they are coupled up through double spur-wheel gearing to the motors. The arrangement for running on the adhesion part of the line is as follows: A friction-clutch coupling is keyed on to the intermediate shaft and transmits the power from this by spur-wheel gearing and connecting-rods to the adhesion axles. In principle the general construction is that of the Engelberg locomotive, Fig. 73.

In conclusion, it may be mentioned that the Blonay-les-Pleiades and the Altstätten-Gais railway lines are intended to be brought into service during the present summer. Both these lines have metre gauge and Strub's rack-gear. The first line works with mixed locomotives similar to those on the Montreux-Glion line, the second line has six-wheeled motor carriages having bogies similar to the Monthey-Champéry type. 
FIG. 75.-Monthey-Champery Railway.

Gauge

Rack Systom

Maximum Gradient

Minimum Radil of Curres:

Speeds

Tractive Power Maximum .
$1,000 \mathrm{~mm}$. (3 ft. $3 \frac{\mathrm{a}}{9}$ in.).

Strub.

34 in 250.

60 metres (197 ft.).

10 and $25 \mathrm{~km}$. per hour $(6 \cdot 2$

and $15 \cdot 5$ miles per hour)

$8,000 \mathrm{~kg} \cdot(7 \cdot 8$ tons $)$.

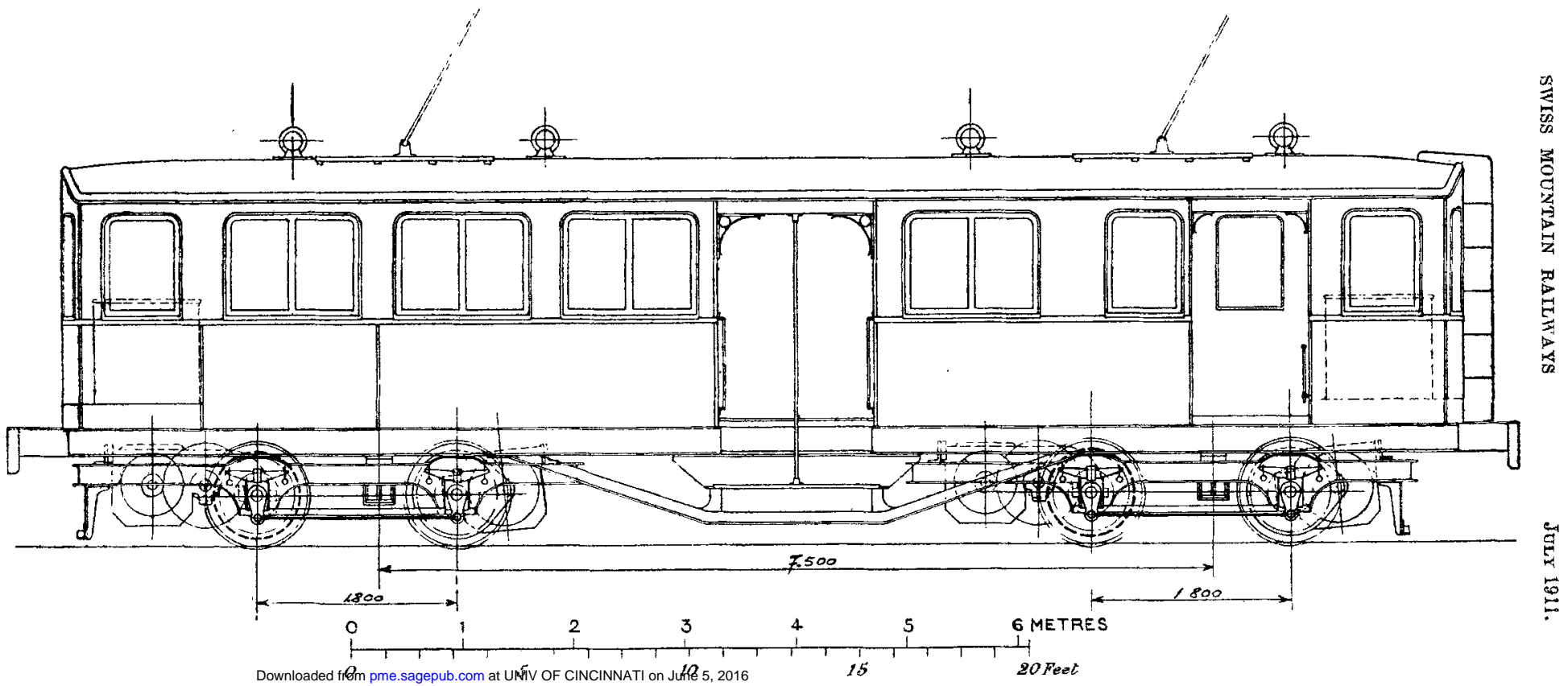


The locomotives and motor-cars already described were all designed at the Winterthur Locomotive Works, which carried out the mechanical part; the electric equipment was constructed and furnished by the different Swiss electric firms: Brown, Boveri and Co., Baden; Maschinenfabrik Oerlikon; Elektricitätsgesellschaft Alioth, Münchenstein, Cie. électrique et mécanique, Geneva.

Switzerland has a total of 120 steam locomotives as well as forty-five electric locomotives, and motor coaches arranged for working with rack gear. The total length of the rack railways is $140 \mathrm{~km}$. (87 miles).

In conclusion, the diversity of the construction of rack-gearing locomotives in Switzerland has given those connected with the Swiss locomotive industry an opportunity of exercising their experience in the construction of rack-railway locomotives owing to the continually increasing demands made by the problem.

The Paper is illustrated by 22 Figs. in the letterpress.

[The Discussion on this Paper was combined with that on the Paper by Mr. E. Huber-Stockar, and commences on page 570.] 


\section{Discussion.}

The Presidext said the members had already by their acclamation accorded their thanks to Mr. Huber-Stockar for the very excellent Paper he had presented, which contained information on a subject that was creating an immense deal of interest in England; in fact, the "Battle of the Phases" recalled the "Battle of the Gauges" of the middle of the last century. The discussion on Mr. Huber-Stockar's Paper would be taken together with the discussion on the Paper on the Rack-Railway Locomotives of the Swiss Mountain Railways by Messrs. J. Weber and S. Abt.

In proposing a hearty vote of thanks to Messrs. Weber and Abt for their very interesting Paper, the President said the rackrailways of Switzerland were the admiration of the world. He had been struck during the reading of the Paper by the fact that there was a curious connection between the Swiss railway system and the Institution, namely, that the year 1847 in which the Institution was founded was the year in which the first railway was opened in Switzerland.

The resolutions of thanks were carried by acclamation.

Dr. EDward Hopkixson, Member of Council, in opening the discussion, said the first Paper by Mr. Huber-Stockar had a distinctly historical flavour about it, and he thought wisely so, because it often struck him that engineers would do well to pay more attention to the history of their science. A greater study of engineering work might possibly cause mistakes to be avoided in the future, and would certainly point the way to new developments. That being so, perhaps he might be allowed to make a few remarks also from an historical point of view. He must ask the members to allow him to go back rather further than the authors did, to some twenty-seven years ago, namely, 1884 and 1885. At that time he believed there was no electrical railway or tramway in existence in Switzerland. It was in 1885 that the first electric railway worked entirely by water-power was inaugurated in Irelind. 
That was a railway or tramway, connecting the port of Newry to the manufacturing village of Bessbrook, 3 miles distant, for which he had been both engineer and contractor. He referred to it chiefly because many of the fentures which were characteristic of the working out of the problem then still existed to-day in but slightly altered form. Those were days when the transformer, as we now knew it, did not exist, and the transmission of electrical onergy was entirely by continuous current at voltages rarely, if ever, exceeding 500. It was in the autumn of 1884 that Messus. Gaulard and Gibbs exhibited their transformers, or as they were then called "secondary generators," transmitting alternating currents between Turin and Lanzo. The railway between Newry and Bessbrook was worked by a turbine of 60 b.p., which drove two EdisonHopkinson generating dynamos each of 25 h.p. at 1,000 revolutions per minute. These dynamos were practically as efficient as dynamos of similar ontput to-day, but they cost about $£ 200$ each. $\mathrm{He}$ ventured to say that if generators cost as much now, there would not be an electric railway in Switzerland, and therefore the great development of electric traction was very largely due to the enormous reduction in the cost of generators and motors. The line was of 3 feet gauge, with ruling gradients of 1 to 50 ; the motors were 20 h.p. each, fixed on one bogie of the passenger carriage which had to draw six loaded wagons behind it, so that it was in a true sense a railway. The motors were geared very much the same as motors were geared now. The first step of reduction was by double helical cast-steel wheels, a system still very generally employed, but with the important difference that the gear was now machine cut. At that time the machine cutting of double helical gear was unknown. After the first reduction, the power was transmitted to the axle by a chain-drive.

Perhaps the difficulties of such work at that early stage could hardly be conceived at the present time. Electrical instruments as they were now known did not exist. The hot-wire Cardew voltmeter had only just been introduced. He remembered having to test the voltage of the car by rigging up a Thomson reflecting galvanometer supported on rubber springs, and testing the voltage against a 
(Dr. Edward Hopkinson.)

Clark's cell, and in the same way measuring the current by taking the voltage across a known resistance. The current was conducted to the motors much as it was at the present time by a bow mounted on the roof of the car and rubbing along the under surface of an overhead conductor, though part of the line was on the third-rail system. The voltage was limited by the Board of Trade Regulations to 300 volts. He wished at the time it had been lower because several horses were killed, the compensation for which was an item in the working expenses. Of course such a limitation of voltage made any distant transmission impossible. It was of interest to remark that the original turbine, generators, and motors were, to-day still in regular operation.

Why had there been such an enormous development of electric railway traction in Switzerland in particular? There was the obvious reason of abundant water-power, but he thought there were other not less cogent reasons. The water-power would have been impossible of utilization unless there had been menns of transmitting the energy over considerable distances. It was thus that Swiss engineers, particularly Messrs. Brown, Boveri and Co., were led to direct their attention to the construction of transformers, and then to apply the current, transformed to a suitable voltage, direct to the locomotive in three-phase form without conversion to continuous current.

To that pioneer work of Messrs. Brown, Boreri and Co., Swiss engineers might trace in great measure the real source of the splendid development of electric traction in Switzerland.

Professor Dr. W. Wrssuina (Swiss Polytechnic), speaking in German, said it was difficult to add much to the detailed Paper upon the Electrification of Railways in Switzerland by Mr. HuberStockar. He would, therefore, only refer to a few general points. The question of electric traction in Switzerland was an economic one; the technical side was almost negligible, as well as the question of heavy traffic. The problem was more difficult for other countries. In large towns and their neighbourhood, such as London and New York, where there were railways, both over 
and under ground, as well as heavy traffic, one looked for better systems to deal with the traffic. The question of whether the cost of running would be cheaper did not arise in this connection; a larger output was wanted. In Switzerland the contrary was the case. Most of their railways had no heavy traffic; moreover, they imported almost all their coal from abroad, but they had much water-power available. In this might be the reason for electrification in Switzerland having taken other directions, and for its carrying out having lasted longer. One did not find the boards of management of ordinary (standard-gauge) railways with electric railways working in conjunction with one another; on the contrary, there were a number of typical private railways which were driven electrically. The State railways had not yet introduced electric traction.

The need for cheap running with water-power had led to thorough trials of various electric systems. The high-tension current, as well as the continuons current with low-tension, was applied and very soon the properties of alternating current would be utilized with three-phase driving. In Switzerland they had been the first to endearour to obtain a cheap electric system. When the single-phase motor became of practical use, its application was immediately entered upon. Both in regard to contact lines and single-phtse motors, Mr. Huber-Stockar's Paper and the Maschinenfabrik Oerlikon had rendered great service.

In Switzerland there was an official Commission of inquiry on the running of electric railways. Its work was chiefly theoretical; it endearoured to ascertain with the greatest accuracy from series of trials without actual construction whether the electric running of railways with water-power under Swiss conditions was not more expensive than steam running, and to ascertain therefrom the best system. The present result was that, after the development of single-phase motors, they were sure that electric running of railways with water-power was not at present so expensive as steam running. In future, electric running would become still cheaper, because the hydraulic plants could always deliver the power cheaper in consequence of amortization, while coal rarely became cheaper. 
(Professor Dr. W. Wyssling.)

He wished once more to draw special attention to the fact that one did not yet find in Switzerland large networks of rilways driven electrically, but only interesting isolated instances. The latest example was the single-phase running of the Bern-Lötschberg Railway, formerly the Spien-Frutigen section. Here the contact lines and locomotives were entirely of Swiss construction. The running of the ordinary Swiss railways (of standard gauge) had till now been provided in about the same manner as that in the milway mentionerl. He might also add that numerous electric locomotives of Swiss origin, and new and old ones in foreign countries, showed that their designs differed from those in Germany and America in, the matter of the construction of locomotives, based upon their experience in the construction of steam locomotives. The results showed that they in Switzerland were on the right track.

Mr. Wildiam H. Patchell, Member of Council, thought the Papers formed a most valuable supplement to those read at the Summer Meeting in 1910, and that the members ought to be grateful to the authors for the amount of information contained in them. The introduction of electric power to railways appealed to engineers, first of all as being likely to take place in mountainous countries, or where coal was dear, or for tunnel work. Those who travelled to Switzerland during the previous week would, he was sure, vote for the general introduction of electricity for railway working, particularly for the purpose of settling the dust problem, and he hoped when Parliament took the matter up it would think of it also from that point of view. Curiously enough, the electrification of railways in tunnels lat gone on, not in the tunnels in mountainous countries but in tunnels such as existed in London and New York.

$\mathrm{Mr}$. Huber-Stockar's Paper was a most interesting record of work done, but he wished to ask the author for $n$ little more information. The author quoted the Seebach-Wettingen Railway as taking 32 watt-hours per ton-kilometre for the year of all-round operation (page 482). He would like to know whether the run was a non-stop run. He believed it was, but he was not sure. The difference 
that stopping made was remarkable. One of the very good records quoted at the Toronto Conference was 25.9 watt-hours per tonmile on a non-stop run of about 17 miles. When four stops were made on that run, it increased the power to $58.8^{\circ}$ watt-hours per ton-mile. Mr. Huber-Stockar in the conclusions at which he arrived stated (page 514) that "railway electrification and electrice traction on a large scale is in a great measure a problem of powerstation economics." When looking into the question it wis a little astonishing to find the small difference on the cost of railway operation that a little more or a little less paid for the power used affected the problem. The capital charges and other costs practically put it in the shade.

He hoped the members would receive some information in Switzerland as to the cost of the huge water-power schemes that existed in the country. Mr. Huber-Stockar gave in Table 5 (pages 526-9) the cost of the buildings and station machinery at per 1,000 francs per kilometre. The length of the line was given in kilometres, but he did not think the amount of plant used was given, so that it was impossible to tell what the cost was per kilowatt installed. Even if the figures were given, they would be, perhaps, a little confusing, because in some places the power might be bought, while in other places the complete equipment might be included. If it was not asking too much of the author, he trusted a little more information would be given on that point, and he was sure the members would be grateful to him if he could supply it. He believed in some of the Italian water-power schemes, at Milan, for instance, the steam-stations had cost less than. the water-power stations. English engineers had rather a popular idea that a water-power scheme was the cheapest equipment, but when the pipe-line, the huge dams, and the water storage that was required were included, it was found that it was necessary to pay for much more than the turbines and generators. Before water-power was altogether put on one side by the Diesel engine, as he had heard suggested, he hoped the Institution would be able to have some of those figures put on record, 
Mr. J. Wraber said that he had not much to add to the Paper on "Rack-Railway Locomotives." The construction of these locomotives formed an important problem. A careful study of the designs, the application of the best kinds of materinl and thorough workmanship, were absolutely necessary for their execution. The design and the construction of the various kinds of brakes specially demanded careful attention.

'Though the construction of rack-rail locomotives was a speciality of the Swiss Locomotive Works, he knew that English locomotive builders, such as Beyer Peacock and Co. and the North British Locomotive Co., had built good working rack-locomotives.

One point which he thought would be of some interest to the members was that the introduction of superheated steam for rackmil-locomotives by the Winterthur Locomotive Works was a complete success. As was known, on the heavy gradients of rackrail lines the locomotives had to work with heary steam admission (40 to 50 per cent.); the water-level had to be as high as possible in the boilers, so the steam would introduce relatively a large percentage of water with it into the cylinder. 'This would explain why rack-rail locomotives equipped with Schmidt's steam superheaters had caused a large saving of coal and water. A new locomotive for the Pilatus Railway was built five years ago with a Schmidt superheater; it burned 40 to 43 per cent. less coal than the ordinary wet-steam locomotives of the same type, of which two were afterwards fitted with superheaters in their boilers with the same good results.

The Rigi-Vitznau Railway, the Bernese Oberland Railway, and the Glion-Rocher-de-Naye Railway, had also made trials this year. with superheated steam and found the coal saving to be from 30 to 40 per cent. This experience showed that the introduction of steam superhenting was to be commended, especially for rack locomotives in Switzerland, where the stations on the line were not too near to ench other.

Mr. E. Hober-Stockar, in reply, said that the 32 watt-hours per kilometre mentioned on page 482 , to which $\mathrm{Mr}$, Patchell 
had referred, was the average of the operations throughout the whole year. The runs were all with five intermediate stops and two terminal stops, with one or two locomotives usually not fully loaded, and with one, two, or three trains at the same time. The figure also included the switching and shunting, and the running at full load and light load as stated in the Paper. With regard to the figures given for buildings and station machinery, he was sorry that it was impossible to obtain conclusive distinctive figures from the official statistics; in no case (except probably the MartignyChattelard) given in the Table was the real central-station machinery included, but only railway-station houses and buildings, with or without the sub-station machinery and apparatus inside. It would have been too complicated to work out the Table in another way; in fact, he would have been obliged to see all the plants and go into their accounts to work out exactly what was machinery and what was not. The figures given for the line equipment contained nothing else but the actual equipment with contact lines, feeders, and so on; therefore, for the non-electrical railways there was nothing given under that head.

The Presidext said that Mr. Patehell's question and Mr. HuberStockar's reply indicated how extremely important it was, and he desired particularly to call the attention of the younger members to the fact that, when drawing deductions from figures, it should be clearly understood how those figures were obtained. It was often stated that anything could be proved by figures. The figures themselves would never make mistakes; the mistakes were made by those who drew false inferences from them. 